\title{
EVALUATION OF MULTILEVEL SPRINKLER SYSTEMS AND CONTAINER MATERIALS FOR FIRE PROTECTION IN HIGH-RACK STORAGE
}
W. G. Butturini
J. R. DeMonbrun
J. W. McCormick
L. M. McLaughlin
W. E. Weathersby

\section{UNION CARBIDE CORPORATION}

\section{NUCLEAR DIVISION OAK RIDGE Y-12 PLANT}

operated for the ATOMIC ENERGY COMMISSION under U. S. GOVERNMENT Contract W-7405 eng 26

UNION

CARBIDE
OAK RIDGE Y-12 PLANT

P. O. BOX $Y$

OAK RIDGE, TENNESSEE 37830 


\section{DISCLAIMER}

This report was prepared as an account of work sponsored by an agency of the United States Government. Neither the United States Government nor any agency Thereof, nor any of their employees, makes any warranty, express or implied, or assumes any legal liability or responsibility for the accuracy, completeness, or usefulness of any information, apparatus, product, or process disclosed, or represents that its use would not infringe privately owned rights. Reference herein to any specific commercial product, process, or service by trade name, trademark, manufacturer, or otherwise does not necessarily constitute or imply its endorsement, recommendation, or favoring by the United States Government or any agency thereof. The views and opinions of authors expressed herein do not necessarily state or reflect those of the United States Government or any agency thereof. 


\section{DISCLAIMER}

Portions of this document may be illegible in electronic image products. Images are produced from the best available original document. 


\section{Printed in the United States of America. Available from}

National Technical Information Service

U.S. Department of Commerce

5285 Port Royal Road, Springfield, Virginia 22151

Price: Printed Copy \$3.00; Microfiche $\$ 0.95$

This report was prepared as an account of work sponsored by the United States Government. Neither the United States nor the United States Atomic Energy Commission, nor any of their employees, nor any of their contractors, subcontractors, or their employees, makes any warranty, express or implied, or assumes any legal liability or responsibility for the accuracy, completeness or usefulness of any information, apparatus, product or process disclosed, or represents that its use would not infringe privately owned rights. 


\title{
EVALUATION OF MULTILEVEL SPRINKLER SYSTEMS AND CONTAINER MATERIALS FOR FIRE PROTECTION IN HIGH-RACK STORAGE
}

\author{
W. G. Butturini \\ J. R. DeMonbrun \\ J. W. McCormick \\ L. M. McLaughlin \\ W. E. Weathersby
}

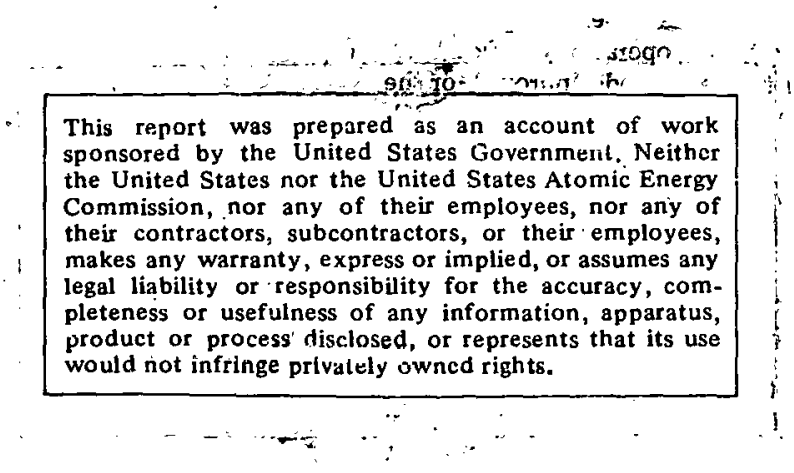

Date Issued - August 27, 1971 


\section{DISTRIBUTION}

Atomic Energy Commission

Jackson, L. H.

Keller, C. A.

Lenhard, J. A.

Zachry, D. S., Jr

Oak Ridge Gaseous Diffusion Plant

Jordan, R. G.

Wilcox, W. J., Jr

Oak Ridge Y-12 Plant

Abele, H. M.

Bernander, N. K.

Bostock, D. J.

Burditt, R. B.

Burkhart, L. E.

Butturini, W. G.

DeMonbrun, J. R. (20)

Denny, A. (2)

Foulk, D. L.

Hemphill, L: F.

Hodges, J. W.

Kahl, K. G.

Keith, Alvin

Kite, H. T.

Marrow, G. B.

McCormick, J. W.

McLaughlin, L. M.

McLendon, J. D.

Mitchel, G. W.

Parsons, J. A.

Smith, H. F., Jr

Smith, R. D.

Tench, F. M.
Trotter, T. C.

Weathersby, W. E. (5)

Wesley, R. L.

Yaggi, W. J.

$Y-12$ Central Files (5)

$Y-12$ Central Files (master copy)

$Y-12$ Central Files (route)

$Y-12$ Central Files (Y-12RC)

Paducah Gaseous Diffusion Plant

Winkel, R. A.

In addition, this report is distributed in accordance with the category UC-38, Engineering and Equipment, as given in the "USAEC Standard Distribution Lists for Unclassified Scientific and Technical Reports", TID-4500. 


\begin{abstract}
Multilevel sprinkler systems have been designed for fire protection in high-rack storage areas. These systems represent significant improvements over the conventional ceiling sprinkler systems which provide inadequate fire protection in such areas. Many conventional container materials were found to be highly flammable and need a higher degree of protection
\end{abstract}


THIS PAGE

\section{WAS INTENTIONALLY LEFT BLANK}




\section{CONTENTS}

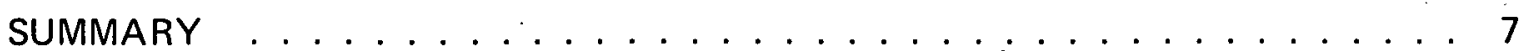

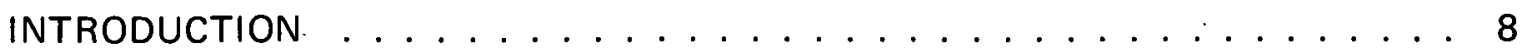

EVALUATION OF COMBUSTIBLE CONTAINERS AND MULTILEVEL SPRINKLER SYSTEMS . . . . . . . . 9

Problem Identity . . . . . . . . . . . . . . . . . . . 9

Combustible Containers ... . . . . . . . . . . . . . . . . 9

Fire Properties of Containers and Packing Materials (Test 1) . . . . . . . . . . 9

High-Rise Storage Systems . . . . . . . . . . . . . . . . . . . . . . 10

Typical High-Rack Area with Ceiling and Intermediate Sprinklers (Test 2) . . 10

Typical High-Rack Area with Ceiling Sprinklers Only (Test 3) . . . . . . . . . 12

Typical High-Rack Area Using Improved Containers (Test 4) . . . . . . . . . . 15

Typical High-Rack Area Containing Cardboard Material and Ceiling Sprinklers Only (Test 5) . . . . . . . . . . . 19

Typical High-Rack Area Containing Cardboard Material and Both Ceiling and Intermediate Sprink lers (Test 6) . . . 22

Typical High-Rack Area Containing Cardboard Material and Both Ceiling Sprinklers and Intermediate Sprinklers with a Metal Shield (Test 7) . . . . . . . . 27

Conclusions and Recommendations . . . . . . . . . . . . . . . 27

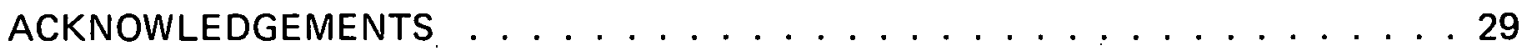

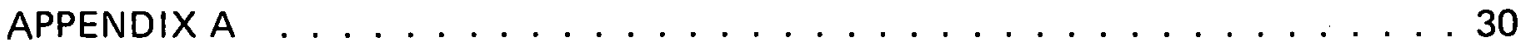

Detailed Description of Test $1 \ldots \ldots$. . . . . . . . . . . 30

First Test . . . . . . . . . . . . . . . . . 30

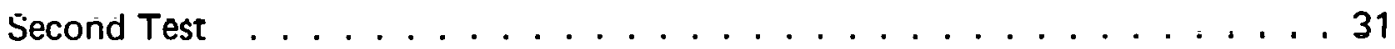

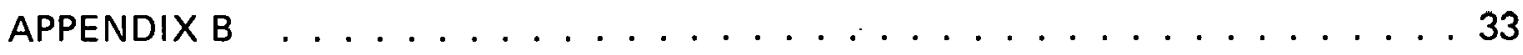

Fire Protection for the High-Rack Fire Tests . . . . . . . . . . . . . 33

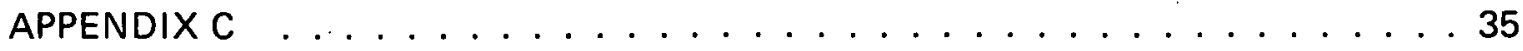

Rack Layout and Loading Arrangement for Test $2 \ldots \ldots$. . . . . . . . . . 35

Top Plan View . . . . . . . . . . . . . . . . . . . . 35

Loading Arrangement . . . . . . . . . . . . . . . . . 35

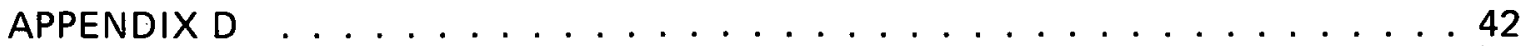

Loading Arrangement for Test $4 \ldots \ldots \ldots$. . . . . . . . . . . . . 42 


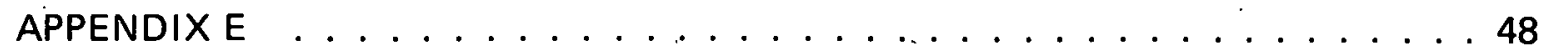

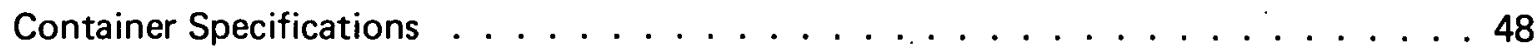

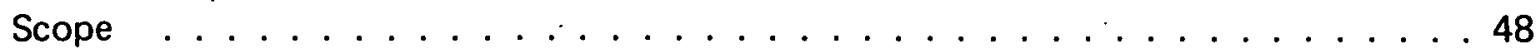

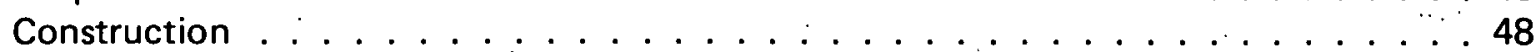

Packing Material . . . . . . . . . . . . . . . . . . . . . 48

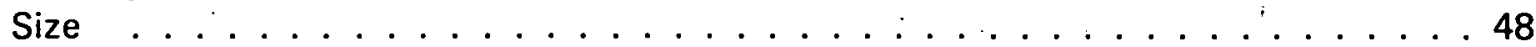

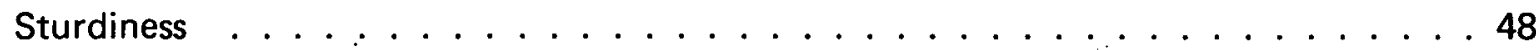

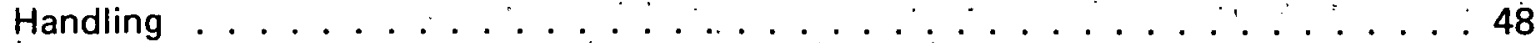

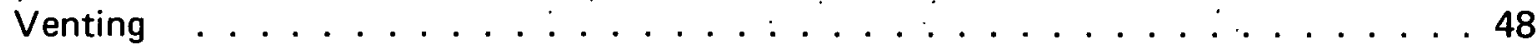




\section{SUMMARY}

Recent installation of high-rack storage facilities in the Oak Ridge Y-12 Plant, ${ }^{\text {(a) }}$ coupled with the extensive use of flammable container materials, has presented fire protection problems which cannot be handled by conventional means. Tests were conducted to evaluate multilevel sprinkler systems and to determine what changes, if any, are needed in container materials. A typical high-rack facility was constructed and equipped with multilevel sprinklers. The shelves were filled with typical container types and a fire source was ignited.

Tests revealed the following facts:

1. Multilevel sprinklers are extremely effective in controlling fires in high-rack storage facilities.

2. Ceiling sprinklers above the racks are inadequate to control fire propagation.

3. There was no apparent necessity for other controls such as gravity ventilation, bulkheads, draft curtains, or smoke detectors.

4. Plastics, cardboard boxes, and other flammable containers should be eliminated or enclosed in less-flammable outer containers.

(a) Operated for the US Atomic Energy Commission by the Union Carbide Corporation's Nuclear Division. 


\section{INTRODUCTION}

In recent years, the frequency and magnitude of fires resulting from combustibles stored in "high-rack" or "high-pile" configurations have caused the insurance underwriters to review the adequacy of conventional sprinkler systems for fire protection. The insurance underwriters have obtained sufficient results from full-scale testing to indicate that above-average water densities are required to control fires where highly flammable containers are stored in high racks. For the purpose of discussion, "high-rack storage". is generally considered to be storage on shelves supported in a structural metal framework. The shelving material may be a solid, continuous material (either wood or metal); or, it may be open, such as slotted or expanded metal grating. Solid shelving forms a barrier that prevents adequate wetting of materials below the shelving from overhead sprinklers and should be avoided. In some cases, high concentrations of combustibles may require sprinklers at intermediate levels inside the storage racks themselves.

A part of the effort to improve fire control in the $\mathrm{Y}-12$ Plant has been the incorporation of intermediate-level sprinkling systems in high-rack storage areas and perforation of the metal shelving. Since the high-rack areas contain large quantities of plastics and other combustibles, an investigation of new types of fire control has been conducted. The objectives of the investigation were: (1) to determine the relative hazards of various types of container materials, (2) to evaluate the effectiveness of perforated shelves and intermediate sprinklers, and (3) to determine what alterations, if any, were required in either the container materials or fire control systems. 


\section{EVALUATION OF COMBUSTIBLE CONTAINERS AND MULTILEVEL SPRINKLER SYSTEMS}

\section{PROBLEM IDENTITY}

The initial approach of the investigating committee was to identify the most serious fire hazards associated with the containers currently being stored in high-rise racks. A tour was made through several typical storage areas to familiarize the committee with the existing storage situation. The tour was concluded by reviewing a display consisting of various types of containers presently in use. As a result of the tour and review, the committee was able to develop a list of administrative actions which could be adopted immediately in the storage areas, namely:

1. High-rack storage areas will become NO SMOKING areas.

2. Welding or burning will be permitted only by a special permit signed by the Department Superintendent or higher authority. The Fire Department will be notified and a watchman will be provided.

3. All containers will be stored in a closed condition.

4. A cleanliness program will be established to keep combustible trash out of high-rack areas. The area foreman will inspect his area twice each shift.

5. Containers are to be kept as low as the rack space permits.

6. The use of urethane foam will be minimized.

7. An effort will be made to install a temporary alarm system until multilevel sprinklers are installed.

\section{COMRIISTIRIE C.ONTAINERS}

\section{Fire Properties of Containers and Packing Materials (Test 1.)}

Fire properties of the containers and packing materials were not known. Radiant-heat and flame-impingement tests were conducted to determine the mode of combustion. Containers used in the test were typical examples of those being used in the Plant. Details of the test are given in Appendix $A$.

The results of the tests confirmed that polystyrene foam containers represented the greatest hazard in high-rack, high-density storage areas. They also indicated that polyurethane foam, used extensively in $\mathrm{Y}-12$ containers, burns readily. Plywood proved to be a less flammable material for containers. The highly flammable materials inside the steel drums were not ignited, indicating that this type of container does provide protection. The fiberboard and Fiberglas burned, but not very readily. Cardboard boxes burned about as anticipated, although direct impingement was required for ignition. 


\section{HIGH-RISE STORAGE SYSTEMS}

\section{Typical High-Rack Area with Ceiling and Intermediate Sprinklers (Test 2)}

Description - The objective of this test was to duplicate a typical high-rack storage area with a ceiling and intermediate sprinkler system similar to that already designed and under installation in some areas. The containers used in the test were typical of the types currently being stored. Three sections of rack were used. Each rack was 13 feet 6 inches long, 4 feet wide (two each 2-foot-wide shelves back to back) and 18 feet high. There were seven levels of shelves in each rack on 26-inch centers, and all shelving was punched with 1 1/2-inch holes on 3-inch centers. Figure 1 gives a view of the shelving during loading for the test. A detailed description of the fire protection system, including a schematic drawing of the piping, is included as Appendix B.

Thermocouples were installed at various locations throughout the racks to determine temperatures during the fire. Also, temperature-sensitive indicators with a maximum capability of $500^{\circ} \mathrm{F}$ were installed on the front of several containers.

The racks were filled with all types of containers which might be found in high-rack areas throughout the Plant. Plastics such as polystyrene, polyurethane, polyvinyl chloride, polyester, and polyethylene were included along with cardboard boxes, fiberboard drums, and steel drums. The location, type, weight, and Btu value for each container was tabulated. A complete loading arrangement with notes pertaining to the results is included as Appendix C. The storage arrangement was designed to represent the most hazardous situation from a fire standpoint.

The fire was initiated along both sides at the bottom of the center rack. The intent was to use an ignition source which would produce a significant fire, but would not continue to be a fuel source. Since newspaper produces a hot fire and is easily consumed, it was selected as the fire source. Newspapers were piled along the entire face of both sides of the center rack, as can be seen in Figure 1, and were dampened with kerosene. The sprinkler system was a fused-head, automatically actuated system. Fire hoses were on standby should the sprinklers prove to be incapable of controlling the fire.

The polystyrene foam containers ignited very rapidly, as expected, and provided an excellent ignition source for the other containers. Within seconds these containers were burning violently and spreading the fire through the entire lower section of the center rack. Two minutes after flame initiation, the two intermediate sprinklers at the 9-foot level and the south intermediate sprinkler at the 13-foot level actuated in the center rack. The fire was immediately brought under control and, for all practical purposes, was extinguished within one minute.

Findings - The evolution of smoke from burning plastics was of such magnitude that manual firefighting would have been practically impossible in gravity ventilation of one square foot per 50 square feet of floor space. The gravity venting in this test was on the order of 1 square foot per 10 square feet of floor space, yet the entire building was filled with smoke and steam. 


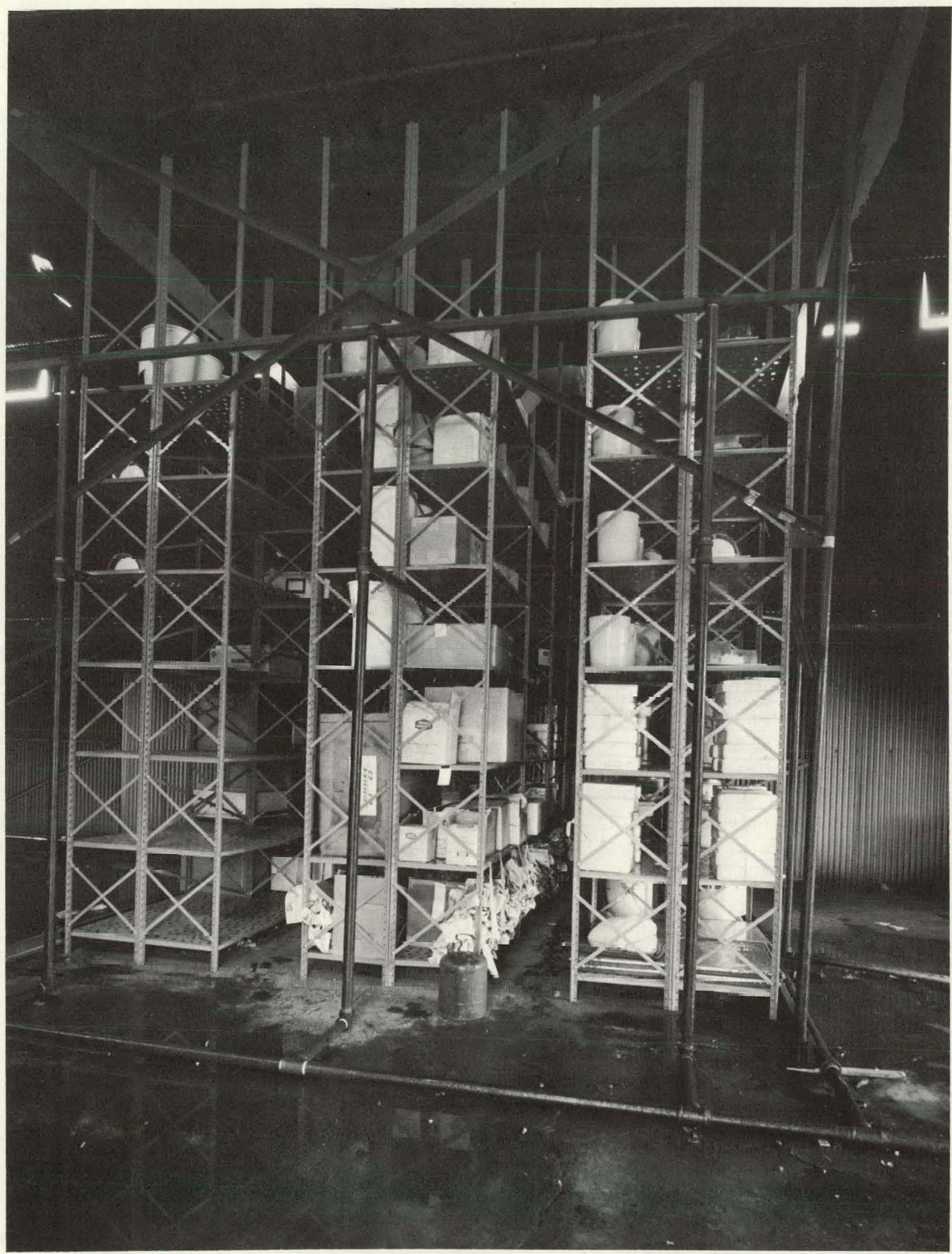

138013

Figure 1. HIGH-RISE SHELVING PARTIALLY LOADED FOR TEST 2. 
The intermediate-level sprinklers were extremely effective in controlling the fire. Only a small percentage of the containers was damaged, and these were principally the highly flammable variety located in the immediate vicinity of the ignition source. The extent of the damage which occurred on each side of the center rack can be seen in Figures 2 and 3 . It should be noted in the photographs that similar containers located across the aisle received only superficial damage.

Smoke detectors would probably have been of little value in this test because the containers ignited so rapidly and burned so readily that sprinkler actuation would have occurred only seconds behind a smoke detector alarm.

The effectiveness of the sprinklers indicates that draft curtains or bulkheads would not have been needed.

The punched shelving was effective in permitting unrestricted water flow where it was not covered by containers, and even the covered areas allowed water to run under to the lower levels.

The thermocouples reacted too slowly to provide meaningful information, and the $500^{\circ} \mathrm{F}$ temperature-sensitive indicators were consumed.

\section{Typical High-Rack Area with Ceiling Sprinklers Only (Test 3)}

Description - Since the racks and most of the containers were still available, a second test was initiated to check the effectiveness of the ceiling sprinklers only. The containers recovered from the second test were rearranged slightly and a second fire was initiated in the middle rack, first shelf, by the use of a butane torch. The intermediate sprinklers were valved out and the ceiling sprinklers remained in service. The fire hurned and spread upward fur live minutes and 10 seconds before two of the ceiling sprinklers actuated. This action caused an immediate suppression of the fire from a height of 14 feet down to about six feet; however, the fire at the lower level spread laterally to adjacent shelving. It soon became apparent that although the ceiling sprinklers were preventing the vertical spread of fire, the flame front was propagating along the lower shelves. The intermediate sprinklers were then valved in, and the heads which had fused in the second test again suppressed the firc very rapidly.

Findings - Intermediate sprinklers provide a highly effective method of fire protection regardless of the type of container construction used and without bulkheads, draft curtains, or smoke detectors.

Ceiling sprinklers alone do not provide adequate protection for high-rack, high-density flammable storage. While the ceiling sprinklers will protect the higher portions of the shelves, indications are that containers on the lower shelves would bc destroyed.

Some redesign or redistribution of containers could reduce the spread of flame. Polystyrene foam appears to represent the greatest hazard and should be totally eliminated or placed in steel, vented containers. Cardboard boxes and exposed plastics should be eliminated or placed in more fireproof containers. 


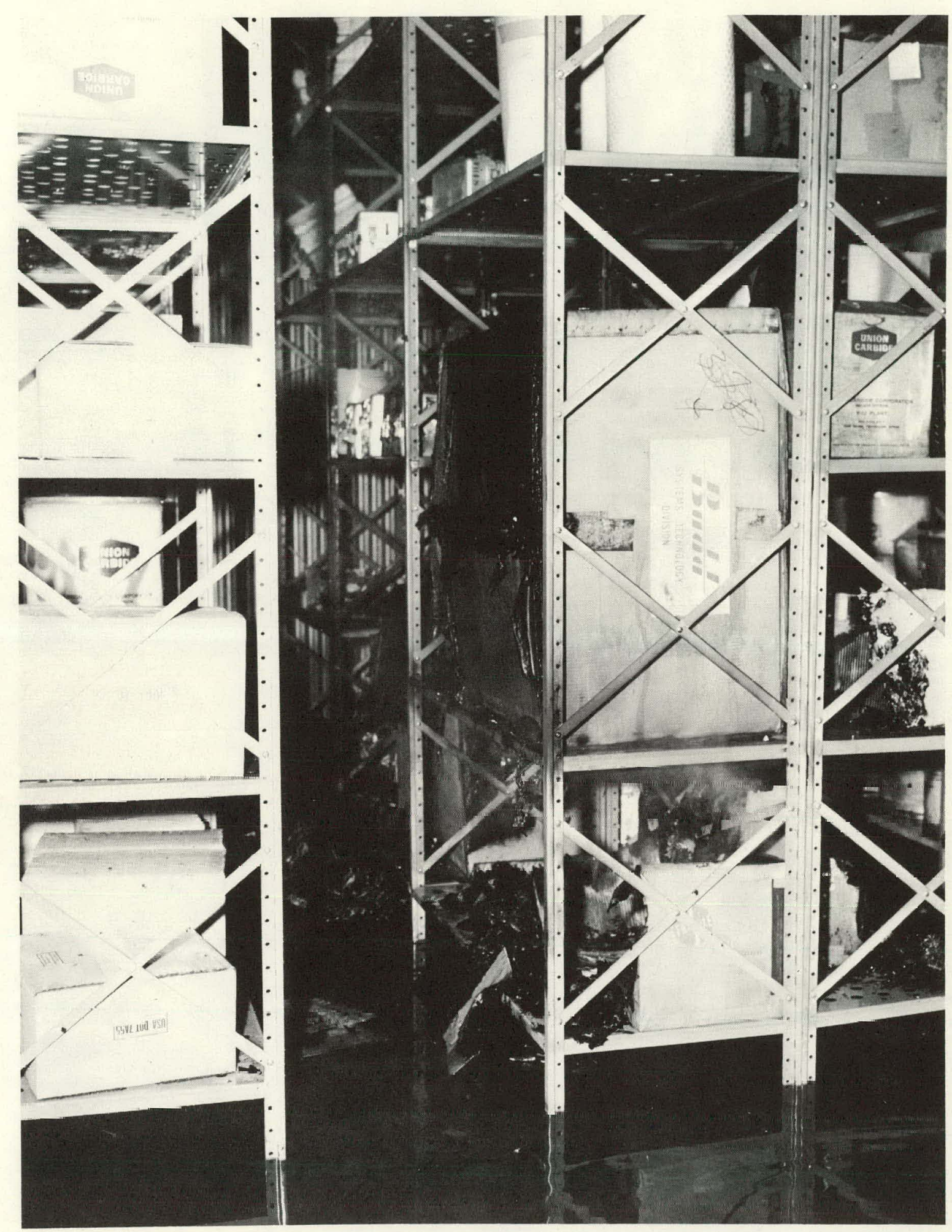

138008

Figure 2. EAST SIDE OF THE CENTER RACK AFTER IHE FIRE. 

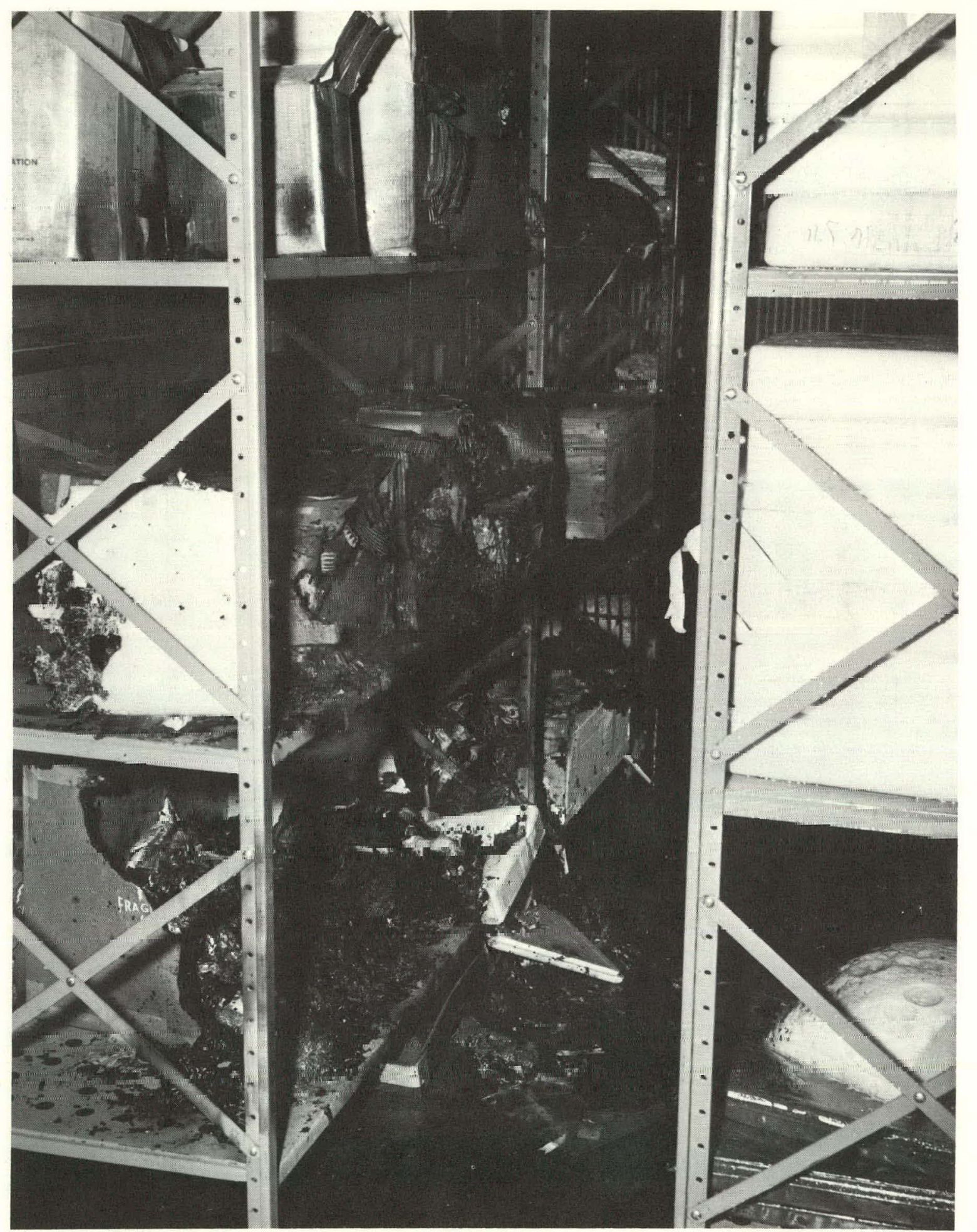

138009

Figure 3. WEST SIDE OF THE CENTER RACK AFTER THE FIRE. 


\section{Typical High-Rack Area Using Improved Containers (Test 4)}

Description - The test series was continued a short time later with improved containers. Since the previous test had demonstrated the effectiveness of the intermediate-level sprinklers with the existing packaging, this test was designed to determine what improvements in fire safety could be effected by the use of more fire-resistant containers. Figure 4 gives a view of the installation during loading for Test 4.

The rack and sprinkler arrangements were the same as in the previous tests, and the water density remained unchanged. Cardboard boxes were eliminated from this test, and extensive use was made of fiberboard drums. Polystyrene-foam containers were placed inside steel boxes and polyethylene containers were placed in galvanized garbage cans. Some wooden boxes were used and several plastic containers, even though flammable, were left exposed to determine the degree of ignition difficulty. Appendix $D$ gives a detailed listing of the rack loading.

The ignition source was identical to that used in the second test; ie, newspapers were wadded up along the bottom shelf of the center section and sprinkled with kerosene. Upon ignition, the newspapers ignited rapidly and burned freely. After a very short time, the heat was sufficient to cause the exposed plastic containers on the second shelf to begin to droop and sag. As the newspapers continued to burn, it became apparent that some of the fiber drums on the first shelf had ignited. But, once the ignition source was consumed, the fiber material smoldered and died out, except for one drum. The exception was a fiber drum containing urethane foam and covered with a plastic lid. The lid melted and the urethane eventually ignited. When this occurred, the flame gradually increased in size and intensity until it ignited one of the plastic containers on the second shelf. This container, in turn, ignited an adjacent container, and soon the fire was of sufficient intensity to actuate the lower intermediate sprinkler head on the south side of the center rack. This single sprinkler completely extinguished the fire in approximately ten seconds.

Findings - The containers used in this test were substantially more difficult to ignite than those used in the second test, although some ignition did occur.

Plastic materials deform very readily in low-heat-level environments and could cause part damage. The photograph of Figure 5 clearly reveals the extent of deformation of the plastic containers on the second shelf.

Plastic lids are undesirable on fiber drums, particularly if the drums contain combustible materials. The one fiber drum which permitted the fire to propagate contained a plastic lid. The amount of damage to the drums and to the plastic containers located immediately ahove can be seen in Fiqure 6.

In the test, polystyrene foam was protected from ignition in metal containers. Substantial melting and deformation occurred, indicating that there was probably considerable outgassing of the foam. The metal containers were vented to preclude any pressure buildup. Views of two examples of polystyrene foam packages which were in the test are presented in Figures 7 and 8 . As seen in Figure 8, the packages tend to insulate each other if not in the immediate vicinity of the fire. 


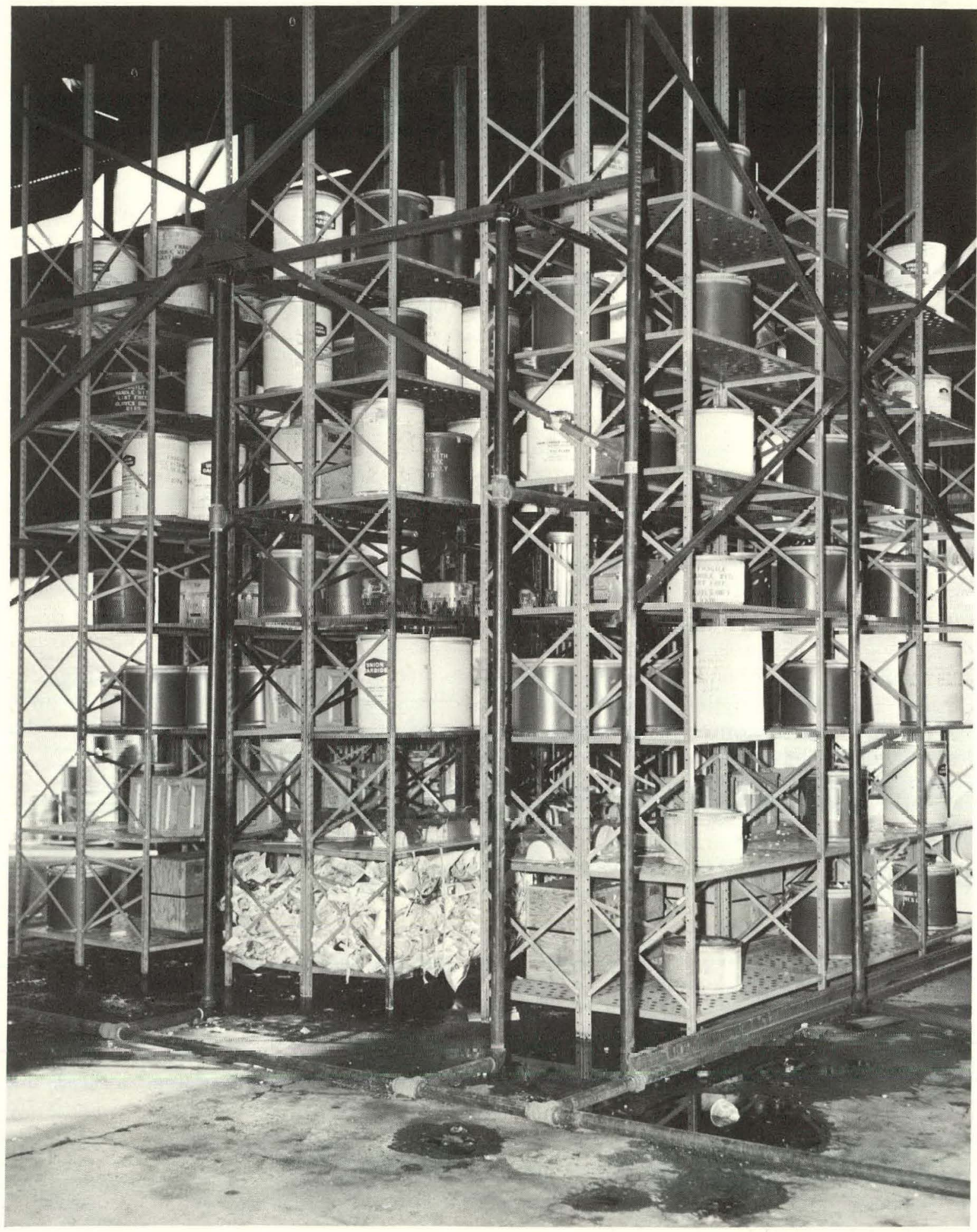

138432

Figure 4. SHELVING PARTIALLY LOADED FOR TEST 4. 


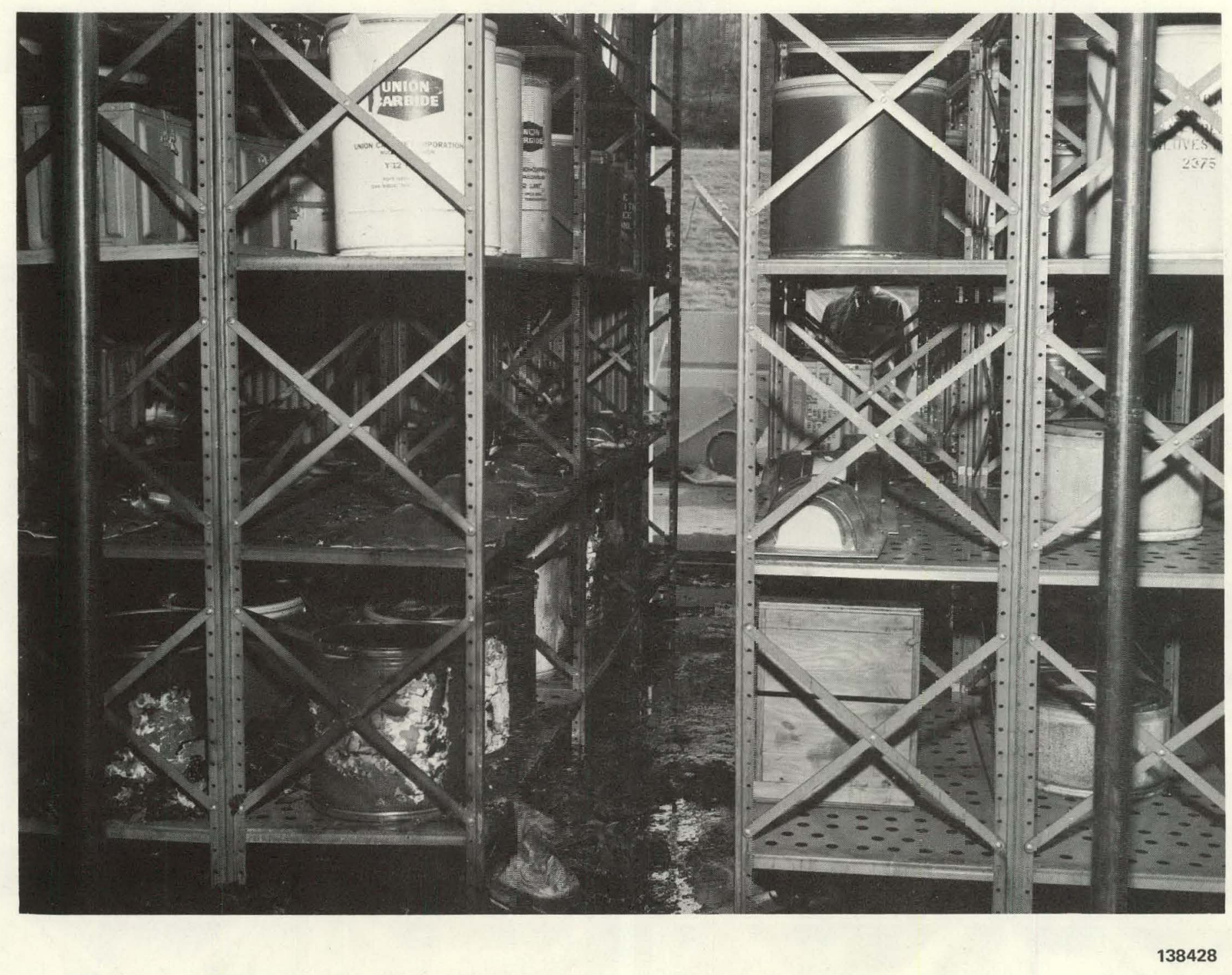

Figure E. WEST AISLE A.FTER TEST 4. 


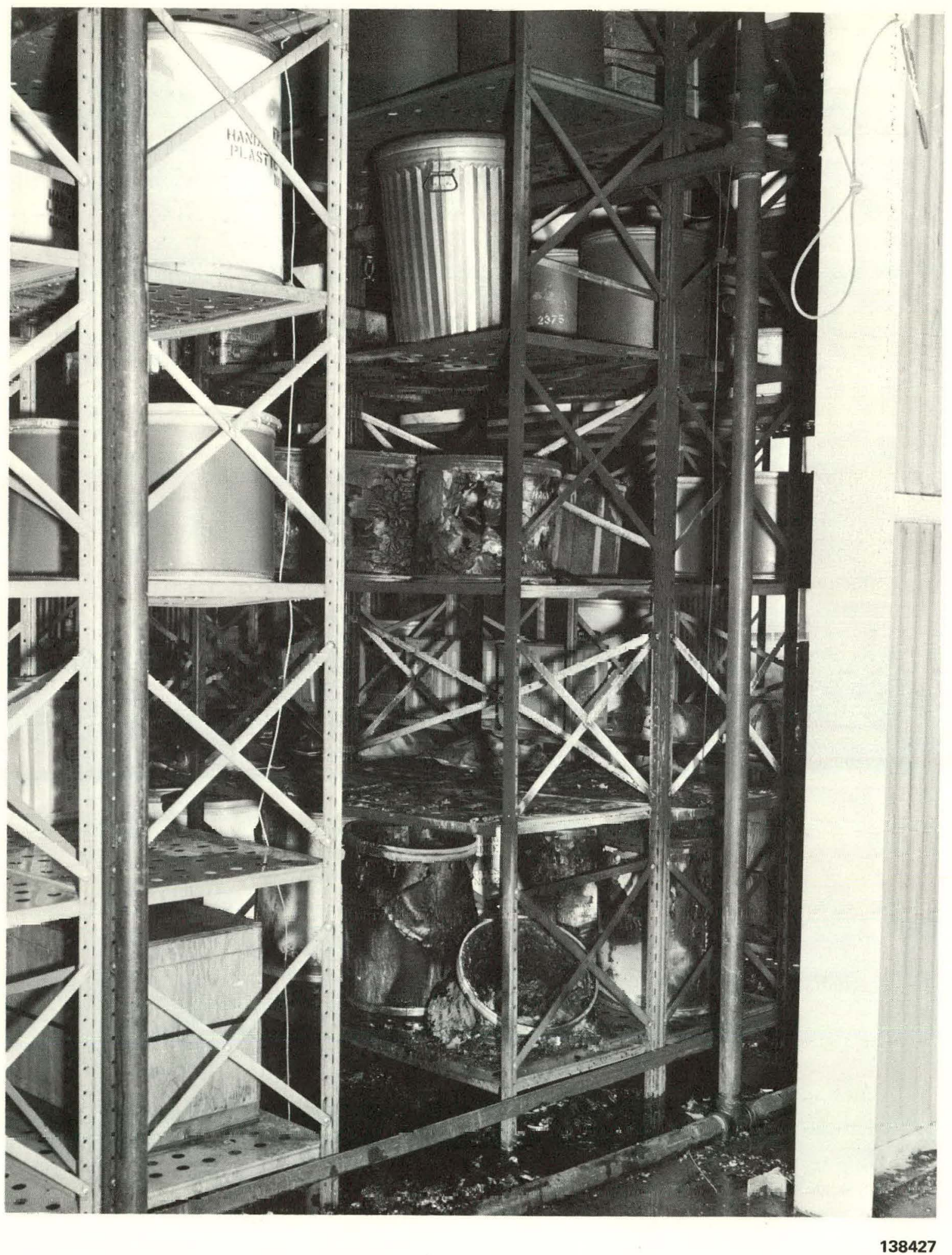

Figure 6. SOUTH CORNER OF THE WEST SIDE OF RACK 2 AFTER THE FIRE. 


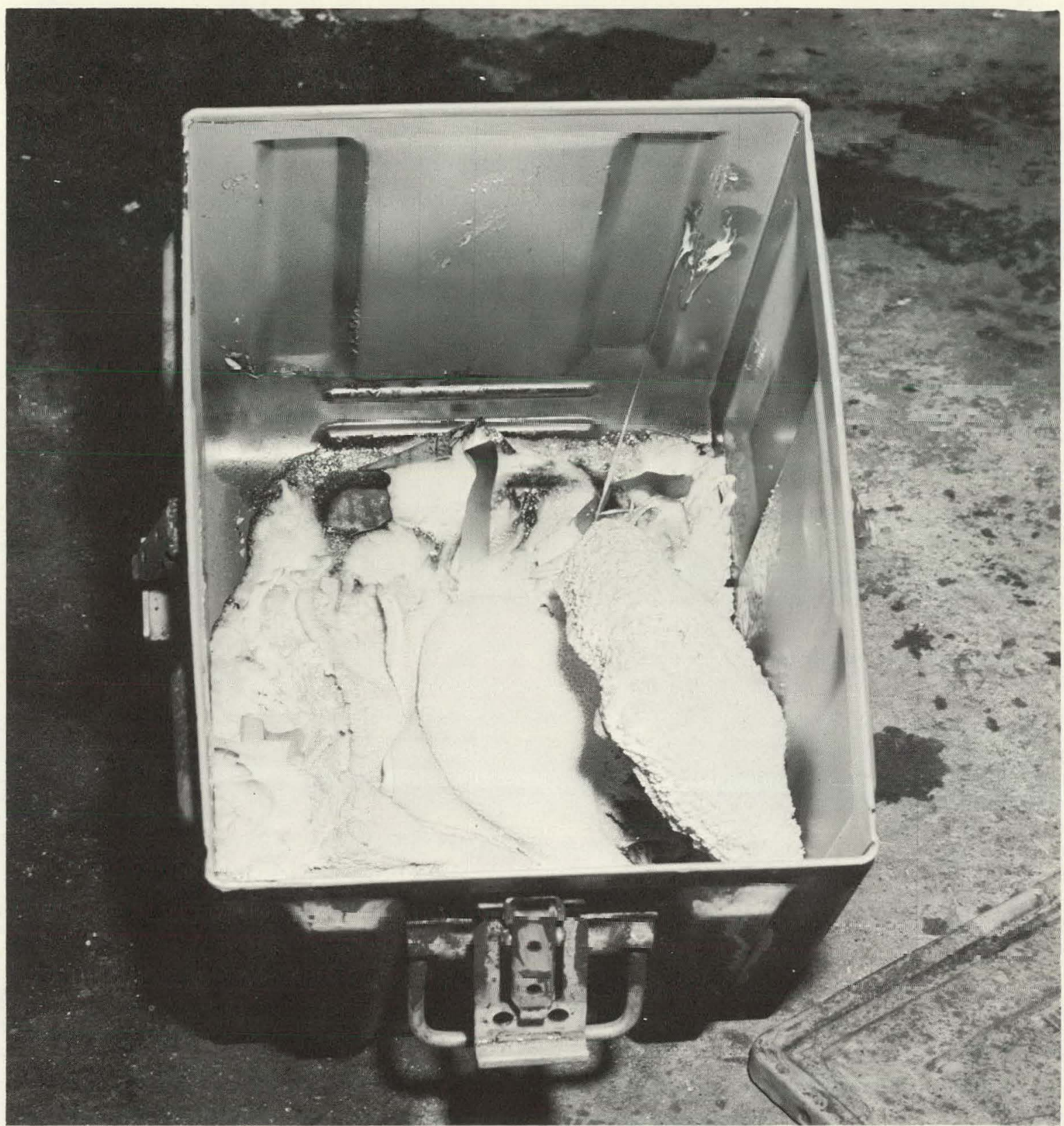

138431

Figure 7. POLYSTYRENE FOAM CONTAINER MELTED DURING FIRE

Propagation of the fire was much slower in this test, and the sprinkler was more effective since the fire was confined to a smaller area.

\section{Typical High-Rack Area Containing Cardboard Material and Ceiling Sprinklers Only (Test 5)}

Description - While the previous tests had been principally associated with handling and shipping containers, Test 5 was the first of a series designed to duplicate a typical high-rack storage area involving cardboard boxes and computer paper and cards. Storage was on 
wooden pallets in high-rack shelving of expanded metal. Fire protection consisted of ceiling sprinklers only.

The storage array in this test was typical of the storage of items of this nature in the $\mathrm{Y}-12$ warehouses. Three sections of rack were used. The middle rack was 12 feet long, 8 feet wide (two each 4-foot-wide shelves back to back) and 12 feet high. There were three levels of shelves on each rack on 4-foot centers. Some storage was directly on the floor. The actual storage height of the commodities was limited to 14 feet. The ceiling sprinkler system was set up as an automatic fused-head $\left(212^{\circ} \mathrm{F}\right)$ system to provide a water density of $0.35 \mathrm{gpm} / \mathrm{ft}^{2}$. The shelving and rack loading for this test can be seen in Figure 9.

Adjacent to the middle rack were two racks used in the previous tests involving containers. These racks were located with an aisle width of 6 feet 8 inches (typical of the Y-12

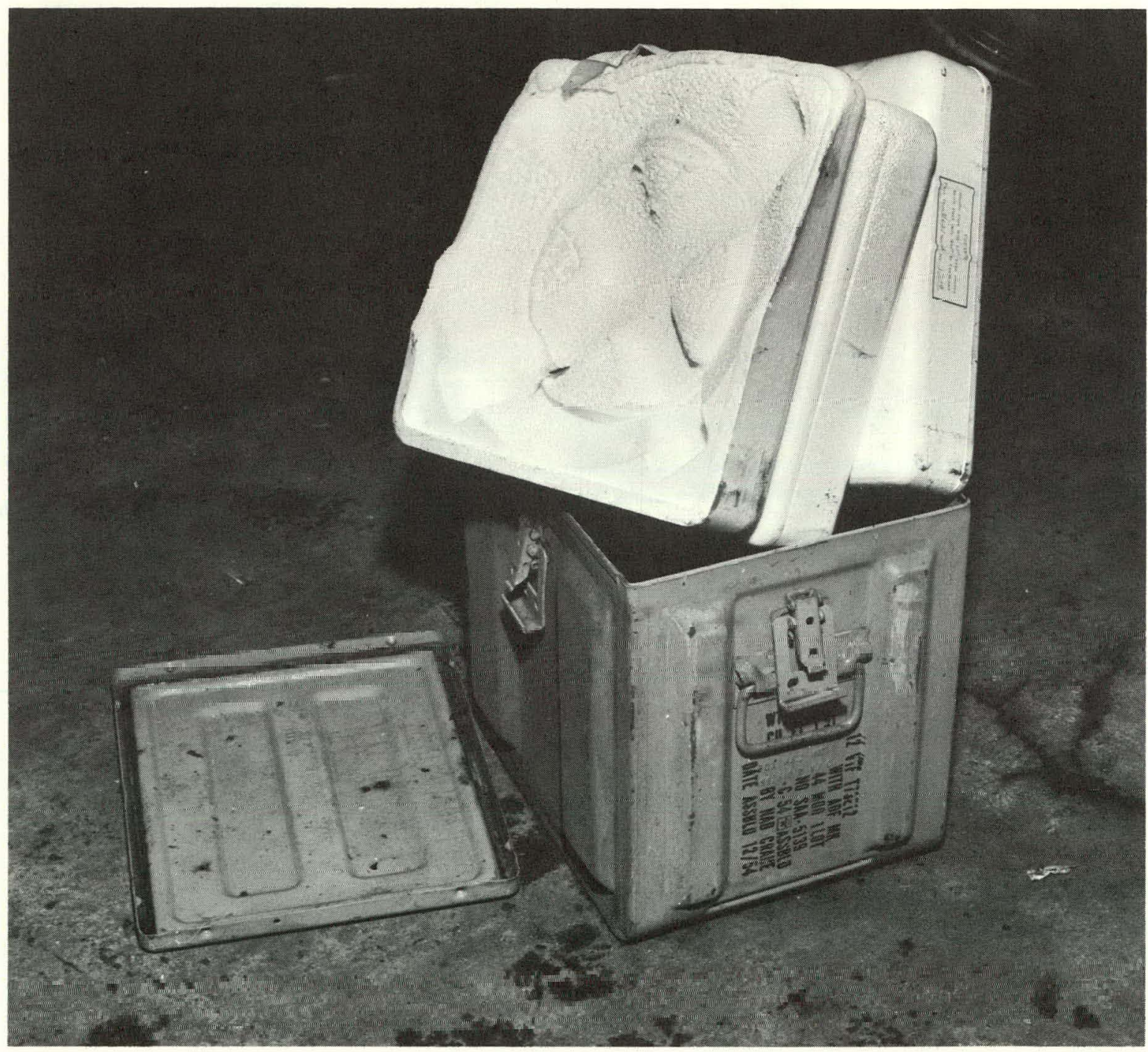

Figure 8. POLYSTYRENE FOAM CONTAINER DAMAGED DURING FIRE. 


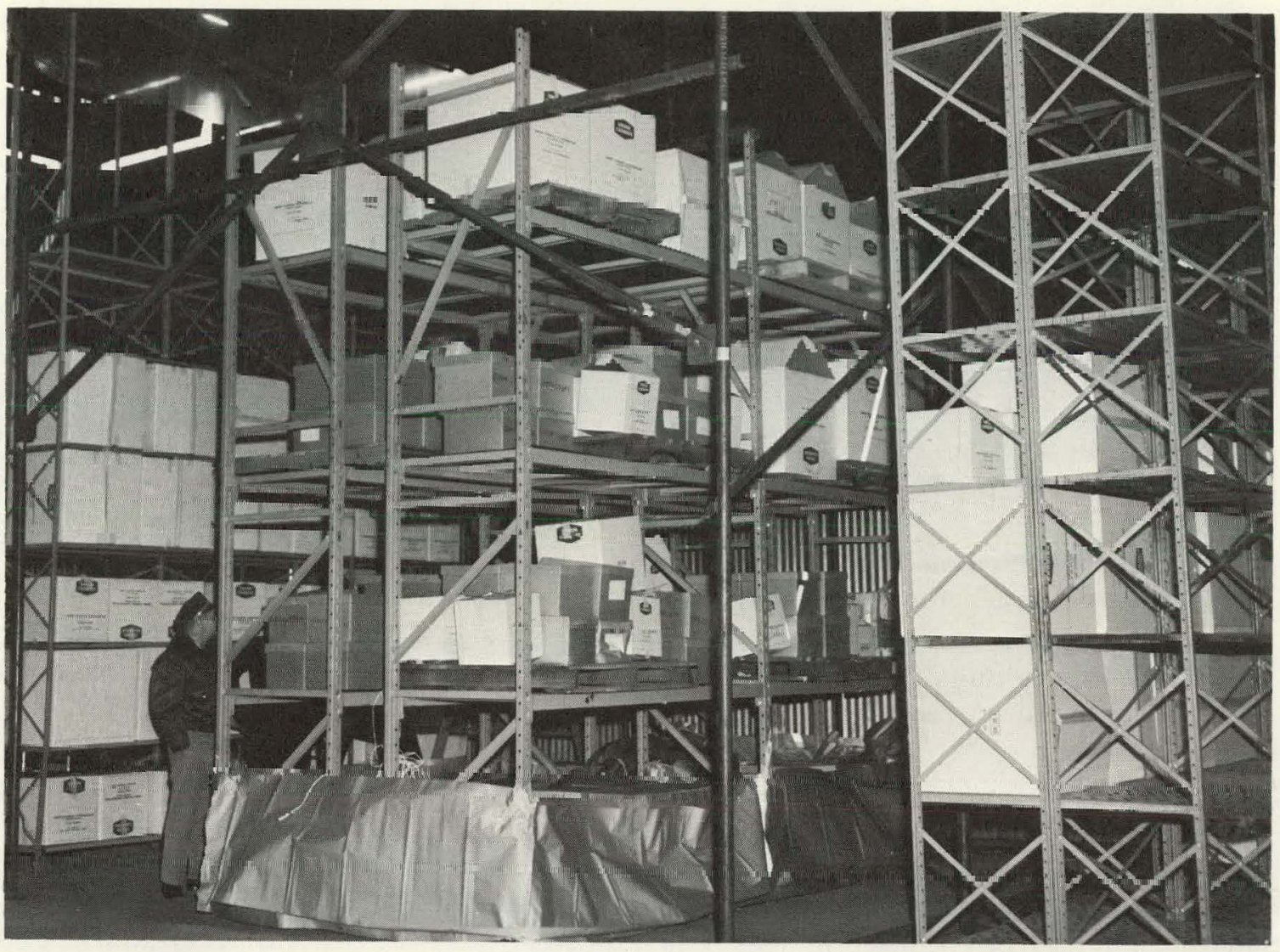

139284

Figure 9. RACK LOADING FOR TEST 5.

warehouse aisles) and loaded only with cardboard boxes. The objective was to ascertain if the fire in the middle rack would jump the aisle and ignite the cardboard boxes.

As on previous tests, paper was placed in the middle of the center rack and ignited. The cardboard boxes and wooden pallets caught fire almost immediately; and, within 59 seconds, the flame reached the 21-foot ceiling. In 71 seconds after ignition, all ceiling sprinklers had fused and were delivering water at the preset density of $0.35 \mathrm{gpm} / \mathrm{ft}^{2}$; but, for all practical purposes the sprinklers were ineffective in suppressing the fire. The ceiling and top shelf were protected, but the items in the lower areas were releasing heat of such intensity that the sprinklers could not control the fire. Although the adjacent racks containing only cardboard boxes were wet from the sprinkler release, the fire did ignite the boxes on the west rack. It soon became apparent that the shelving was being destroyed (horizontal and vertical members began to sag) and a manual fire hose was applied to suppress the fire. All doors and roof vents were opened but the fireman had to leave the area before the fire was extinguished because of visibility impairment. However, there was no further development of the fire; and, in a few minutes, the smoke and steam cleared and the fireman was able to reenter and suppress the remainder of the fire. 
Figure 10 gives a view of the west side of the center rack following the fire. Some of the sagging members can be seen as well as the collapse of the materials into the aisle. The west rack to which the fire jumped after fusing of the sprinkler heads can be seen in Figure 11. There was no ignition of the east rack.

Findings - Ceiling sprinklers providing a water density of $0.35 \mathrm{gpm} / \mathrm{ft}^{2}$ were not effective in suppressing or even controlling the fire in this test.

The condition of the closely stacked computer cards and paper following the fire indicated they were not a principal heat source.

The cardboard boxes and wooden pallets were the major fire source and were releasing heat too rapidly for the sprinkler system to combat.

Ceiling sprinklers alone with a water density of $0.55 \mathrm{gpm} / \mathrm{ft}^{2}$ would have doubtful effectiveness in controlling a fire of this nature.

\section{Typical High-Rack Area Containing Cardboard Material and Both Ceiling and Intermediate Sprinklers (Test 6)}

Description - This was the second test in this series involving the same loading and array as for Test 5, to determine the effect of the addition of one intermediate level of sprinklers compared to ceiling sprinklers alone. The intermediate sprinklers were installed at the 8-foot level between the two 4-foot-wide racks with the sprinkler heads on 6-foot centers. The intermediate heads were fused at $165^{\circ} \mathrm{F}$ and provided a water density of $0.30 \mathrm{gpm} / \mathrm{ft}^{2}$; the ceiling sprinklers were fused at $212^{\circ} \mathrm{F}$ and provided a water density of $0.35 \mathrm{gpm} / \mathrm{ft}^{2}$.

Approximately one minute after ignition, the intermediate sprinkler at the snuth end of the middle rack fused out. This action suppressed the entire fire in this area before there was any ignition in the upper shelves. However, water from this sprinkler appeared to be deflected by the packaging and was spraying into the rack containing the north intermediate head which had not yet fused, possibly onto the head itself. Figure 12, taken after the test, shows the relative positions of the two heads and the absence of fire damage in this area.

The fire in the north portion progressed around the cardboard boxes at the aisle side of the rack and eventually ignited the items on the upper shelves. In approximately 4 minutes and 30 seconds, one of the ceiling sprinklers fused. The fire continued to burn and flames were actually observed on the north intermediate head, but it was noticed that the water from the ceiling sprinkler was completely drenching the north intermediate head. The fire progressed sufficiently through the north end of the rack to actuate two more ceiling sprinklers. Shortly thereafter, the north intermediate head finally actuated and the fire was suppressed. It took approximately an additional seven minutes for the sprinkler system to extinguish the fire. Figure 13 clearly shows that the fire was confined to the north end of the middle rack and reveals how the failure of the north intermediate head to actuate permitted propagation to the upper levels,

Findings - The intermediate-level sprinklers in addition to the ceiling sprinklers prevented the loss of the racks, as was experienced in Test 5. 


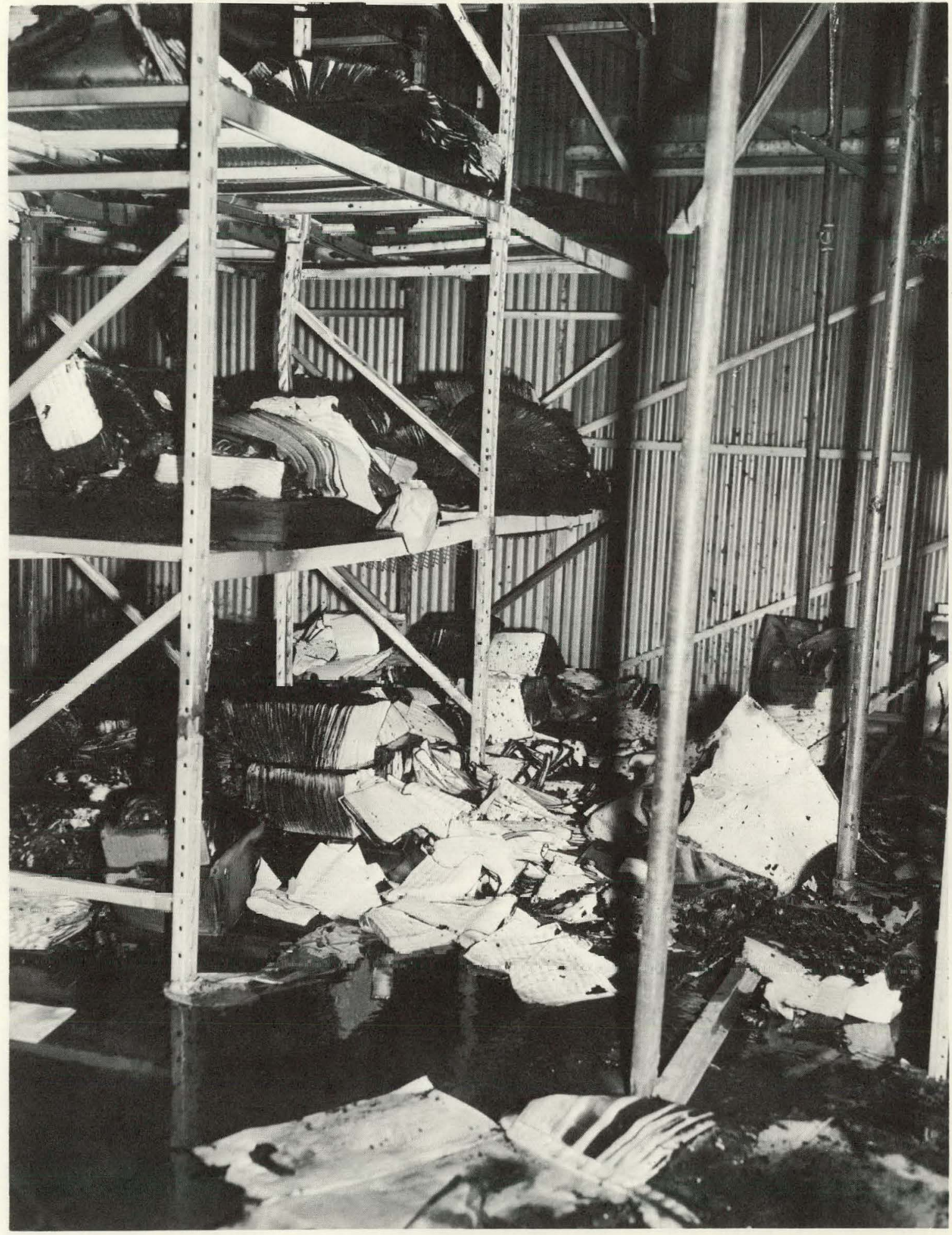

Figure 10. MIDDLE RACK AFTER TEST 5. 

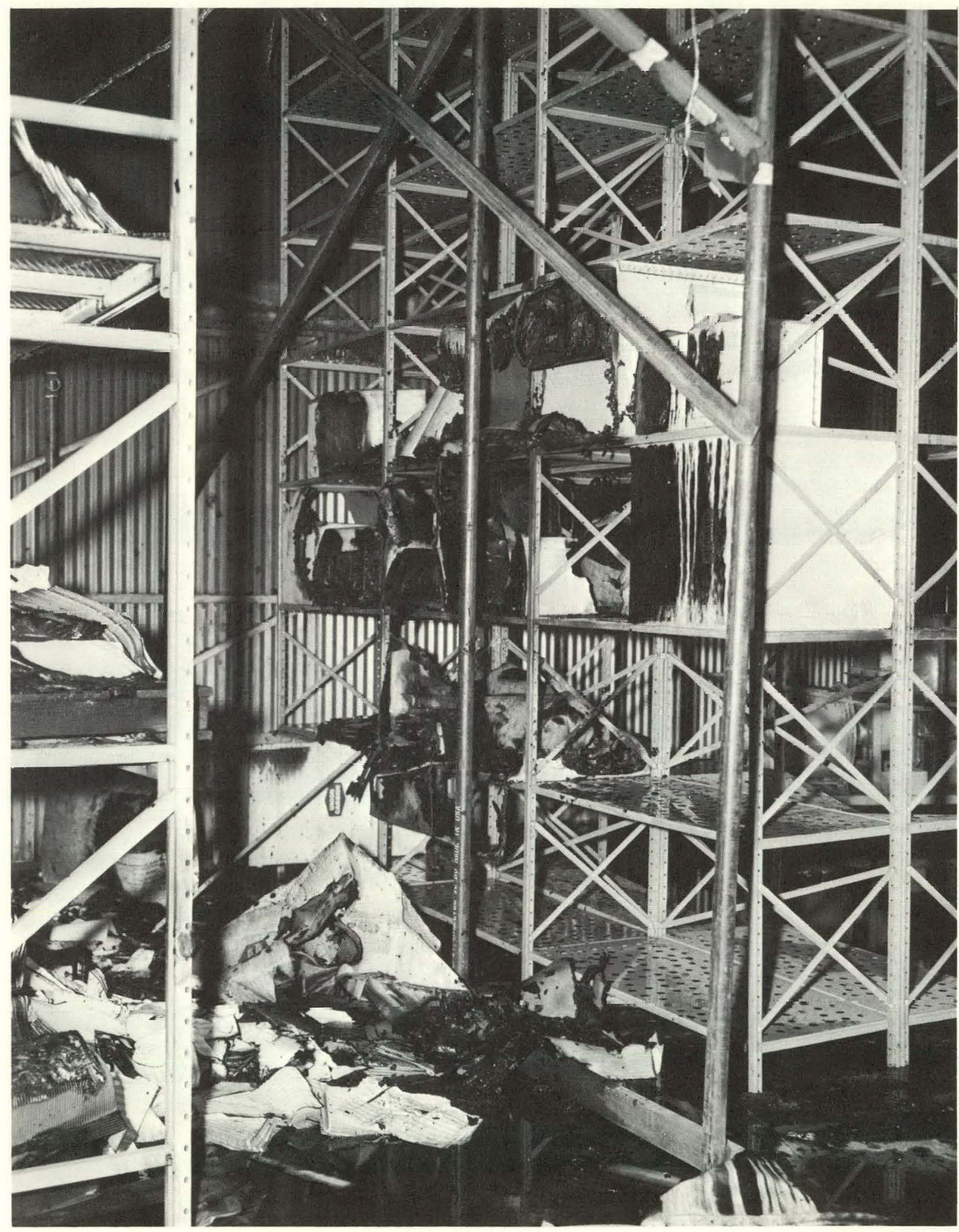

139286

Figure 11. WEST RACK AFTER TEST 5. 


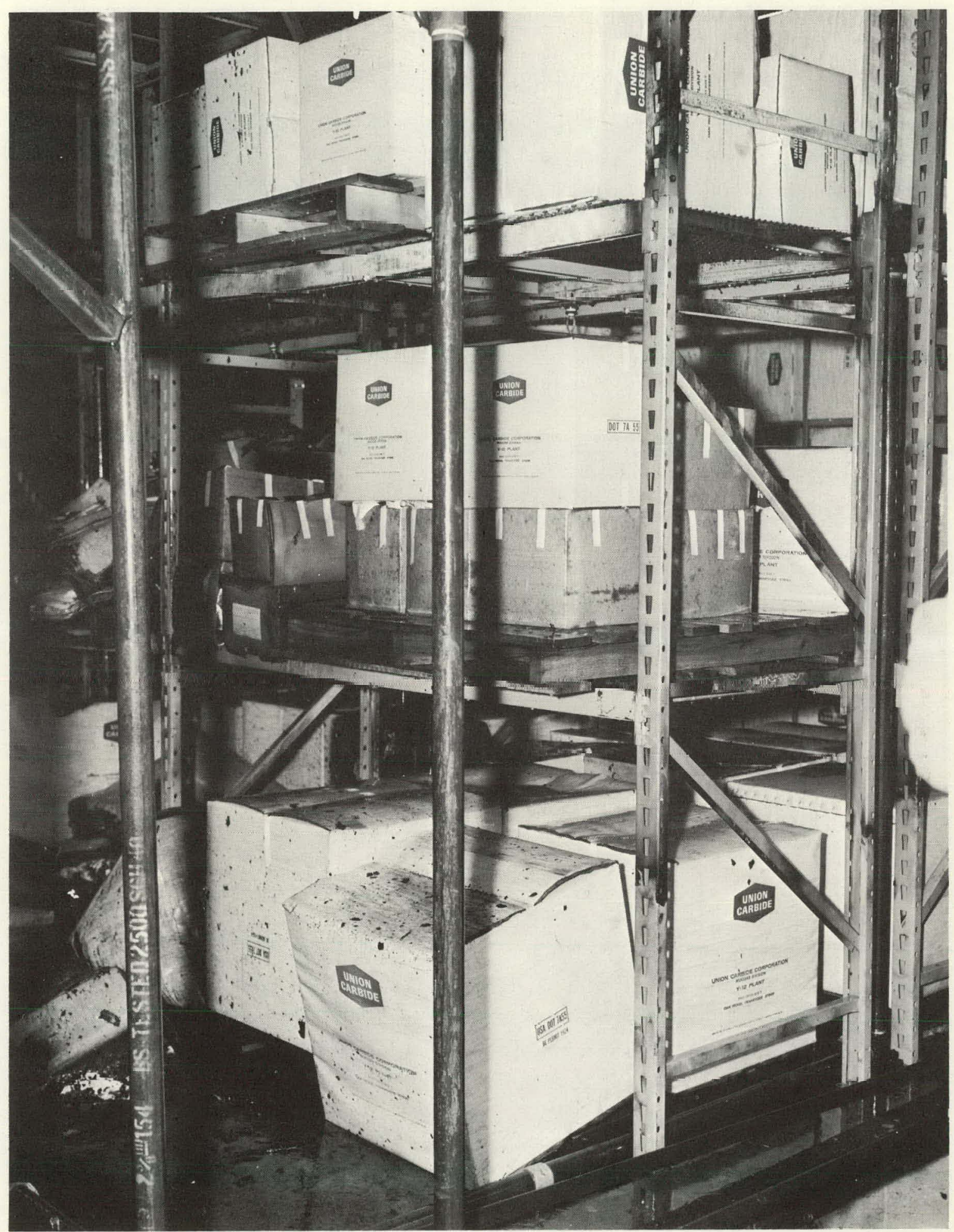

Figure 12. SOUTH END OF THE CENIER RACK AFTER TEST 6. 


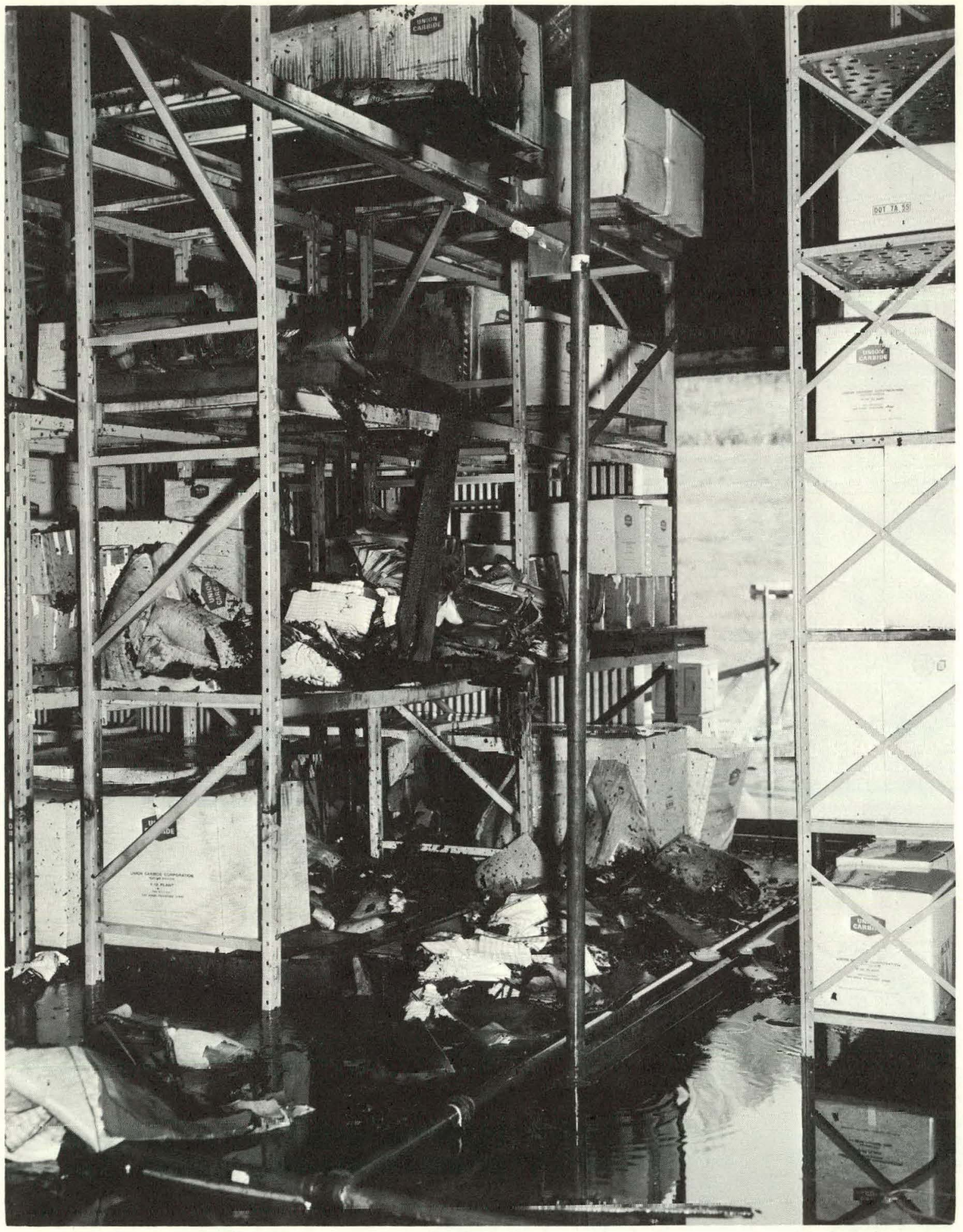

Figure 13. NORTH END OF THE CENTER RACK AFTER TEST 6. 
Intermediate-level actuation would have been faster and more effective if the north head had been protected from the cooling effect of water from the adjacent and overhead sprinklers.

Loss of materials was approximately 30 to 40 percent less than in Test 5 . Had the second intermediate head responded similar to the first, there would have been very little commodity damage.

Typical High-Rack Area Containing Cardboard Material and Both Ceiling Sprinklers and Intermediate Sprinklers with a Metal Shield (Test 7)

Description - The third and final test of this series utilized the same rack array and loading as in Tests 5 and 6 . This test was performed to determine if the addition of a metal shield over the intermediate sprinklers would serve as a heat collector to enhance actuation of the heads. Also, the test was to demonstrate if the shields would prevent "cold soldering" of the intermediate heads if the ceiling sprinklers actuated before the intermediates. Water densities in this test were the same as in Test 6.

Approximately one minute after ignition, the intermediate sprinkler at the south end of the middle rack fused out. A few seconds later, the intermediate at the north end fused. The fire was extinguished before any of the items at the higher elevation were ignited. Commodity damage was limited to the area where ignition occurred and the loss was insigificant.

The wet items were removed from the rack and replaced with dry commodities. An aisle fire was then initiated by placing wadded newspapers in a cardboard box and igniting them. The fire progressed from one shelf to another until all four tiers were on fire. One of the ceiling sprinklers actuated and suppressed the fire at the upper levels, resulting in an intensification of the fire at the lower tiers which progressed laterally through the shelves. Observation was made during this time that water was being shielded from the intermediate heads. Approximately four minutes after actuation of the ceiling sprinkler, the south intermediate head fused out. This action caused a suppression of the fire in the first two levels and the ceiling sprinkler then controlled the fire in the upper tiers.

Findings - The metal shield installed over the intermediate heads was effective as a heat collector and a water shield which greatly improved the operation of the sprinkler system.

Commodity loss in both phases of the test was minimal.

\section{CONCLUSIONS AND RECOMMENDATIONS}

The following conclusions and recommendations can be made as a result of this study:

1. Intermediate-level sprinklers were shown to be extremely effective in protecting high-rack storage areas. Intermediate sprinkler heads should be shielded from water from overhead sprinklers to prevent "cold soldering" if the overhead sprinklers should actuate first. 
2. The plastics evaluated are generally so flammable that they should not be exposed directly to a flame. All plastic containers in high racks should be enclosed in outer containers of low combustibility and low heat conductivity.

3. Plastic lids melt quickly and should be removed and replaced with metal lids. This precaution is particularly important if the containers are tall and contain materials of high combustibility since a flue effect is created.

4. Metal outer containment provides a high level of protection for flammable materials such as polystyrene foam or polyethylene.

5. The principal sources of the most flammable containers evaluated in these tests were vendors and other contractors. These suppliers should be contacted and requested to revise packaging to either eliminate such materials as polystyrene foam, rubberized horsehair, and newspapers, or to provide a safer outer container. Appendix $E$ of this report is a recommended specification to be sent to vendors and other contractors defining the types of containers which should be sent to $Y-12$. It should also apply to containers $Y-12$ sends to other contractors or customers. 


\section{ACKNOWLEDGEMENTS}

The authors wish to thank $H$. E. Crowder of the Dispatching Department who secured the containers and loaded the shelving for these tests; J. T. Blackmon, Jr of the Design Engineering Department for calibrating of the sprinkler system; and members of the Fire Department for the use of the Training Facility and pumping equipment. 


\section{APPENDIX A}

\section{DETAILED DESCRIPTION OF TEST 1}

\section{First Test}

Nine containers of various types were positioned around the periphery of a wood crib fire to determine if radiant heat would cause ignition. Also, the protection afforded by placing plastic material in steel containers was examined.

The following containers were used in the test:

1. A 52 by 52 by 30 -inch plywood container with a built-in pallet and a polyurethane foam insert $\left(6.5 \times 10^{6} \mathrm{Btu}\right)$.

2. A 30-gallon stainless steel drum filled with foamed polystyrene packing material $\left(1.75 \times 10^{5} \mathrm{Btu}\right)$.

3. A 37 by 20-inch-diameter fiberboard drum with a polyurethane foam insert $\left(1.156 \times 10^{6} \mathrm{Btu}\right)$.

4. A 30-gallon steel drum lined with Celotex and a polyurethane foam insert $\left(5.02 \times 10^{5} \mathrm{Btu}\right)$.

5. A 42 by 23-inch-diameter fiberboard drum with a polyurethane foam insert $\left(1.013 \times 10^{6} \mathrm{Btu}\right)$.

6. A 30-gallon steel drum filled with polyurethane foam $\left(1.96 \times 10^{6} \mathrm{Btu}\right)$.

7. Press-formed polystyrene foam containers, 14 inches square and 3 inches deep $\left(2.4 \times 10^{5} \mathrm{Btu}\right)$.

8. A 30 by 30 by 14 -inch polyester-reinforced Fiberglas container with polyurethane foam buns $\left(2.79 \times 10^{5} \mathrm{Btu}\right)$.

9. A 40 by 18 -inch cardboard box with a polyurethane insert $\left(2.473 \times 10^{6} \mathrm{Btu}\right)$.

All containers were placed four feet from the edge of the crib fire.

Thermocouples were placed on the face, inside, and back side of some of the containers to determine the radiant heat temperatures. The location of the thermocouples is shown in Figure A-1.

Approximately five minutes after igniting the wood crib, a maximum temperature of $1,010^{\circ} \mathrm{C}$ was reached in the crib. None of the containers ignited although some deformation of the press-formed polystyrene containers was noted because of melting. However, the temperature at this point did not allow hand contact. Some "steaming" of the 


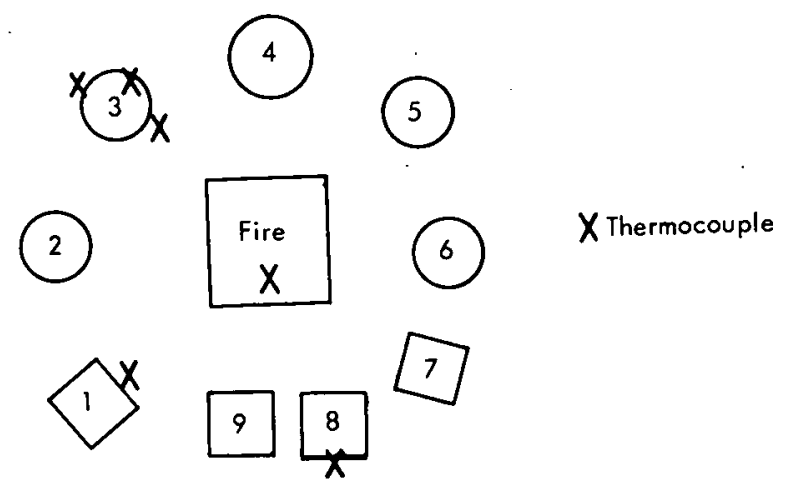

Figure A-1. LOCATION OF THE THERMOCOUPLES.

52 by 52 -inch plywood box was observed. Eventually, the wood-crib fire collapsed and the fire temperature dropped to $640^{\circ} \mathrm{C}$. Table A-1 lists the maximum temperatures observed during the test.

Table A-1

THERMOCOUPLE TEMPERATURES DURING FIRST TEST

\begin{tabular}{clr}
$\begin{array}{c}\text { Thermocouple } \\
\text { Number }\end{array}$ & \multicolumn{1}{c}{ Location } & $\begin{array}{r}\text { Temperature } \\
\left({ }^{\circ} \mathrm{C}\right)\end{array}$ \\
\hline $1-7$ & Crib Fire & 1,010 \\
$2-8$ & Polyester Container & 0 \\
$3-9$ & Plywood Container & 180 \\
$4-10$ & Fiberboard Drum - Inside & 100 \\
$5-11$ & Fiberboard Drum - Rear & 125 \\
$6-12$ & Fiberboard Drum - Front & 140 \\
\hline
\end{tabular}

The conclusions were that even at these low temperatures the polystyrene foam containers were damaged, but there was no indication of damage to the other containers.

\section{Second l est}

The partially damaged polystyrene containers were relocated to the front top of the 52 by 52 -inch plywood container, and all the remaining containers were repositioned such that the collapsed crib fire was impinging on each container. The polystyrene containers ignited immediately, melted, and flamed across the top of the plywood box. The fiberboard drums, cardboard box, and polyester container ignited.

Temperatures observed in this test are listed in Table A-2.

This test provided the following information:

1. The polystyrene foam containers behave much like flammable liquids when exposed to an open flame in that they ignite readily, flow easily, and burn intensely.

2. The polyester-reinforced Fiberglas container ignited, but was only partially burned. 
Table A-2

THERMOCOUPLE TEMPERATURES DURING SECOND TEST

\begin{tabular}{clc}
\hline $\begin{array}{c}\text { Thermocouple } \\
\text { Number }\end{array}$ & \multicolumn{1}{c}{ Location } & $\begin{array}{c}\text { Temperature } \\
\left({ }^{\circ} \mathrm{C}\right)\end{array}$ \\
\hline $1-7$ & Fire & - \\
$2-8$ & Polyester Container & 400 \\
$3-9$ & Plywood Container & 990 \\
$4-10$ & Fiberboard Drum - Inside & 870 \\
$5-11$ & Fiberboard Drum - Rear & 280 \\
$6-12$ & Fiberboard Drum - Front & 670 \\
\hline
\end{tabular}

3. The fiberboard container with a polyurethane insert and no lid was almost destroyed. Once the fire broached the outer wall and was able to melt and ignite the urethane, a flue effect became apparent. This action is confirmed by the $200^{\circ} \mathrm{C}$ temperature differential between the interior of the container and the face. The similar fiberboard container with a lid was only about 25 percent destroyed by the fire.

4. The plywood container held up very well although the polystyrene burned directly on its top surface. The front side (next to the fire) was charred but the wall was not broached, and there was no apparent damage to the polyurethane insert.

5. A noticeable sound was heard from the steel drum containing the polystyrene foam packing material. Apparently, pressure was formed inside from vaporization of the foam during the fire. The foam was completely melted but did not burn.

6. The steel drum containing the Celotex protected the polyurethane foam insert.

7. All rubber gaskets on the drums ignited, indicating that nonflammable gasket materials are desirable. 


\section{APPENDIX B}

\section{FIRE PROTECTION FOR THE HIGH-RACK FIRE TESTS}

The area immediately over the high racks contained a steel-plate ceiling that was 21 feet above the floor. Eight automatic sprinklers, fused at $212^{\circ} \mathrm{F}$, were installed on this ceiling. These sprinklers have a $17 / 32$-inch orifice, and water is supplied by a two-inch main to provide a water density of $0.53 \mathrm{gpm} / \mathrm{ft}^{2}$. Since the area encompassed by the racks involved 344 square feet, the water demand was $183 \mathrm{gpm}$.

In addition to the ceiling sprinklers, there were two levels of intermediate sprinklers installed in the racks with two sprinklers at each level in each rack. The lower sprinklers were at approximately 9 feet and the upper sprinklers at about 13 feet. These intermediate sprinklers provided a total of 12 heads fused at $165^{\circ} \mathrm{F}$ with an orifice of $1 / 2$ inch. A two-inch main supplied the water to provide a density of $0.30 \mathrm{gpm} / \mathrm{ft}^{2}$ at the 13 -foot level and $0.25 \mathrm{gpm} / \mathrm{ft}^{2}$ at the 9 -foot level. The water demand was $189 \mathrm{gpm}$. Thus, the total water demand for all sprinklers was $372 \mathrm{gpm}$ and was supplied by two fire hoses from the 1,000-gpm Fire Department pumper. Each header was equipped with a globe valve to control flow and a pressure gauge to indicate when the sprinklers automatically actuated. Figure B-1 is a schematic drawing of the sprinkler arrangement for Tests 2,3 , and 4. 


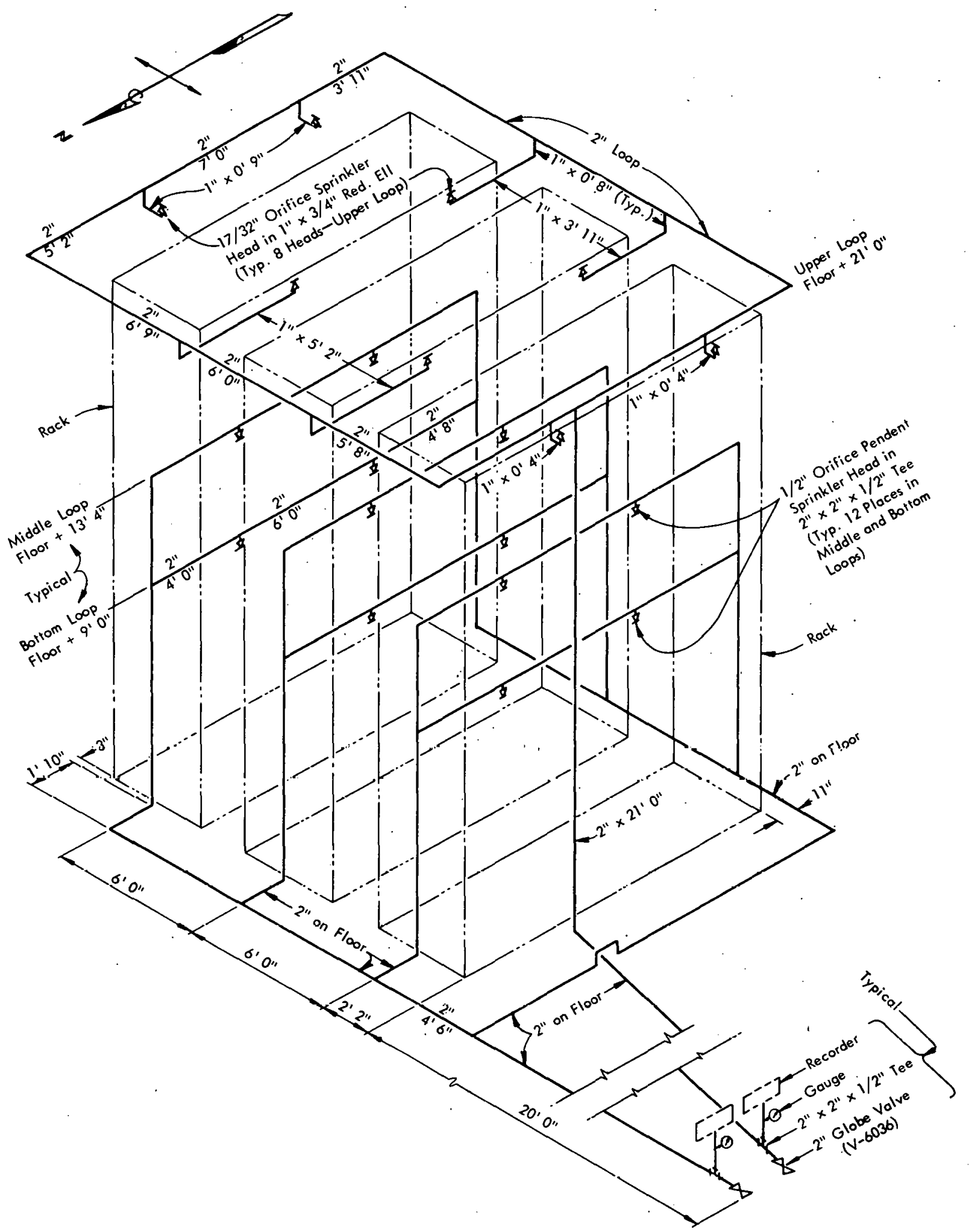

Figure B-1. SPRINKLER SYSTEM FOR FIRE TESTS 2, 3, AND 4. 


\section{APPENDIX C}

RACK LAYOUT AND LOADING ARRANGEMENT FOR TEST 2

Top Plan View

NA

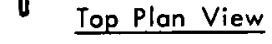

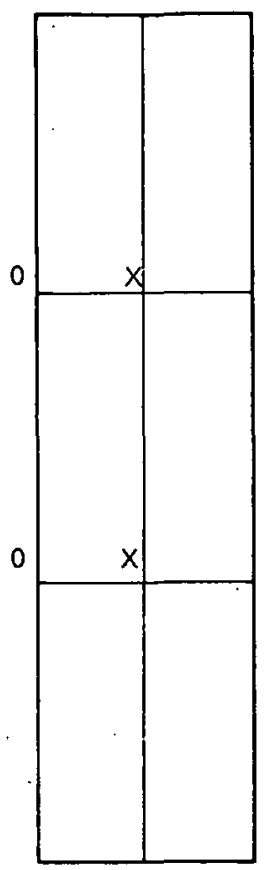

Rack 1

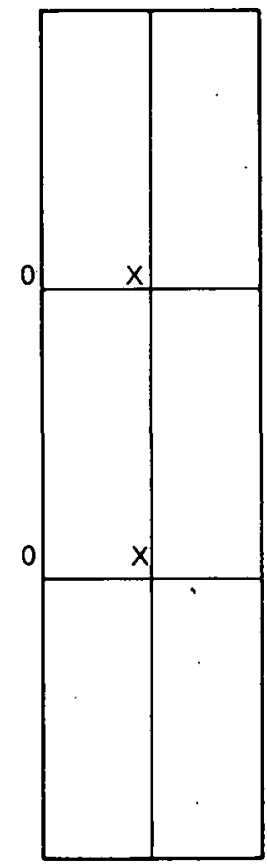

Rack 2

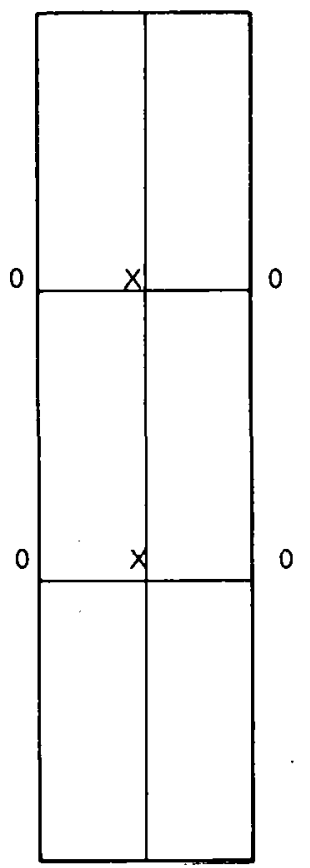

Rack 3

Figure C-1. TOP PLAN VIEW OF THE HIGH RACKS. ( $\dot{X}$ - Intermediate Sprinklers at the 9 and 13-Foot Levels; $O$. Ceiling Sprinklers at the 21-Foot Level) 


\section{Loading Arrangement}

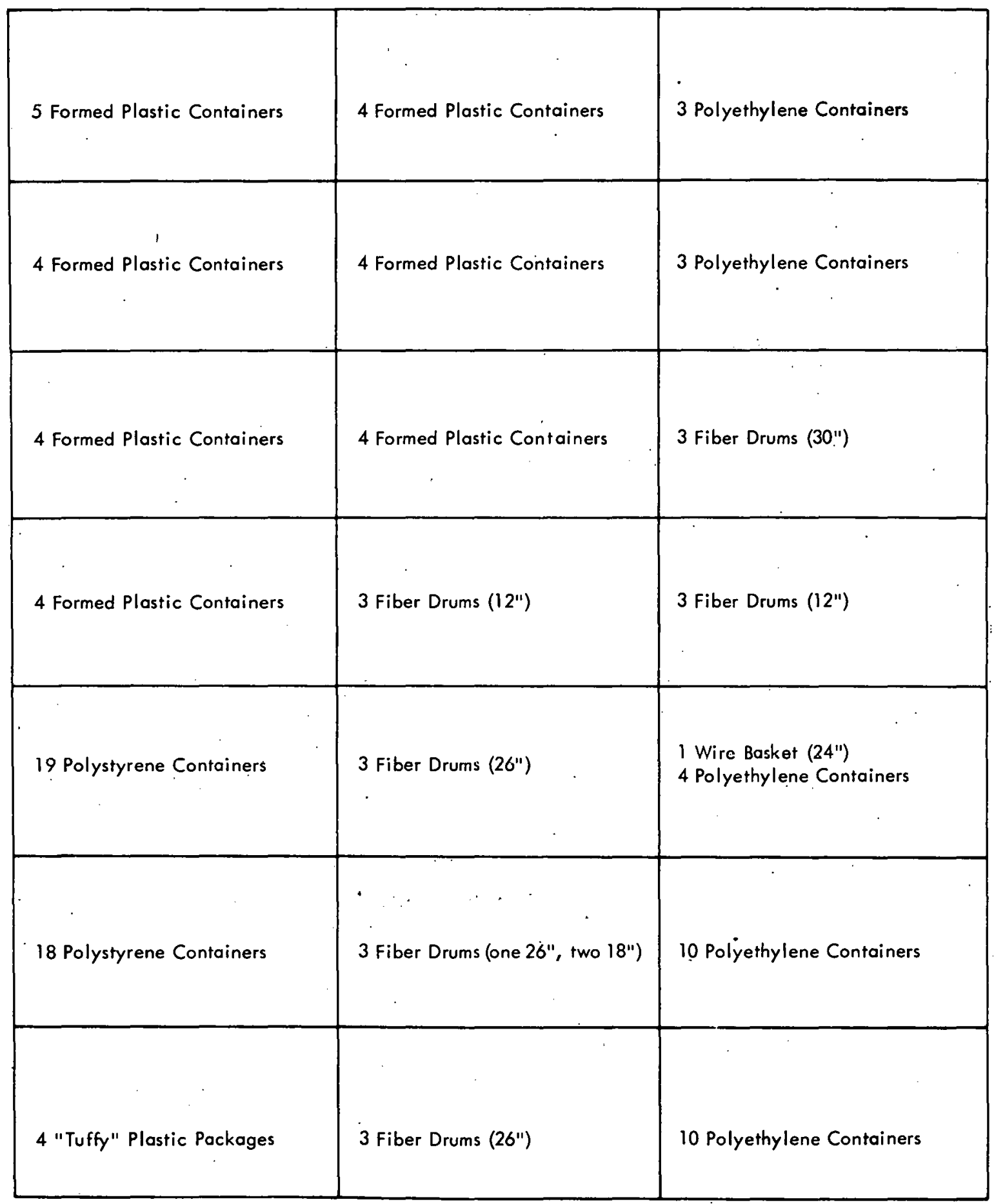

Figure C-2. RACK 1 - WEST SIDE. (Fire Load - $5.6 \times 10^{6}$ Btu) 


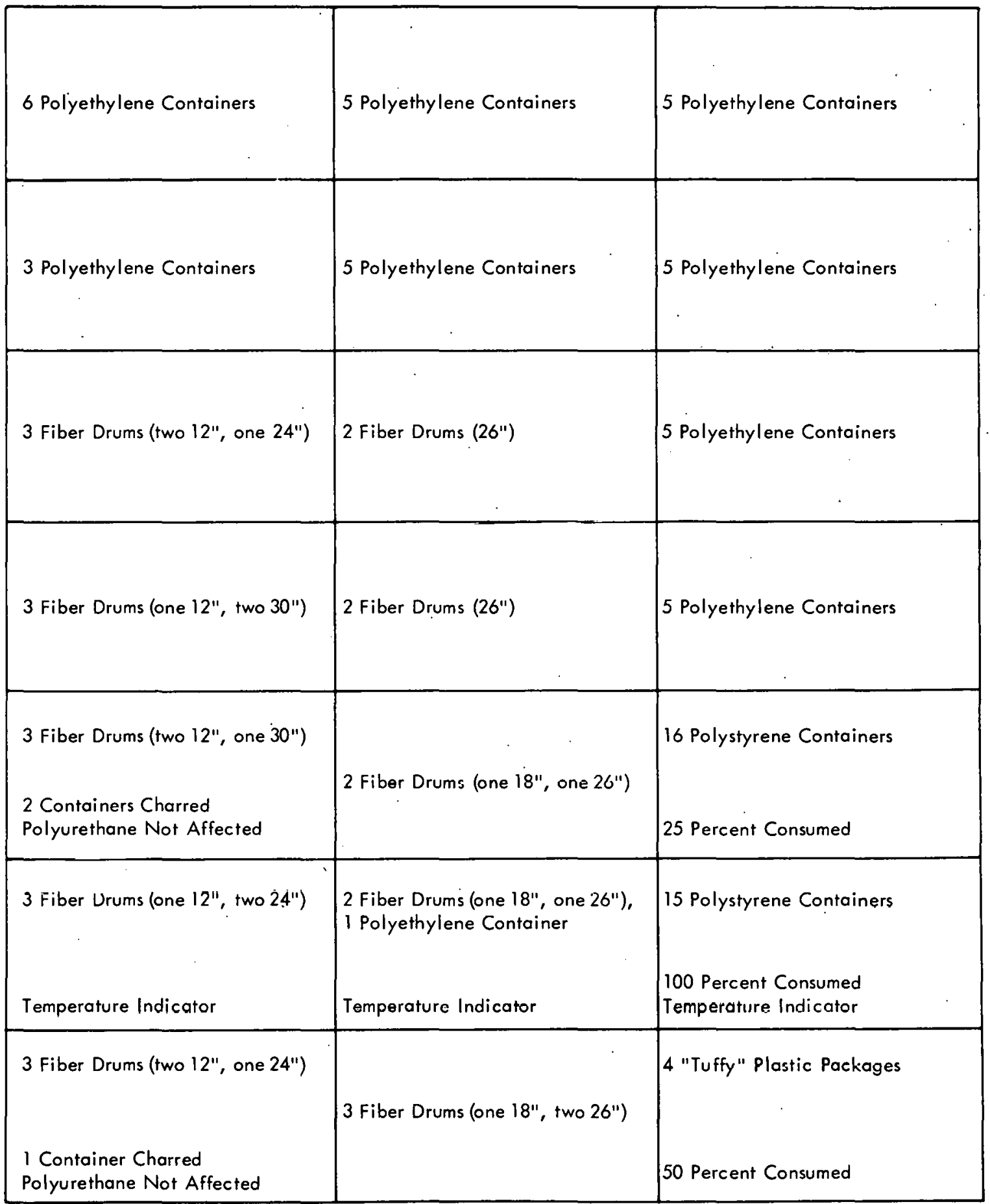

Figure C-3. RACK 1 - EAST SIDE. (Fire Load - $5.5 \times 10^{6}$ Btu) 


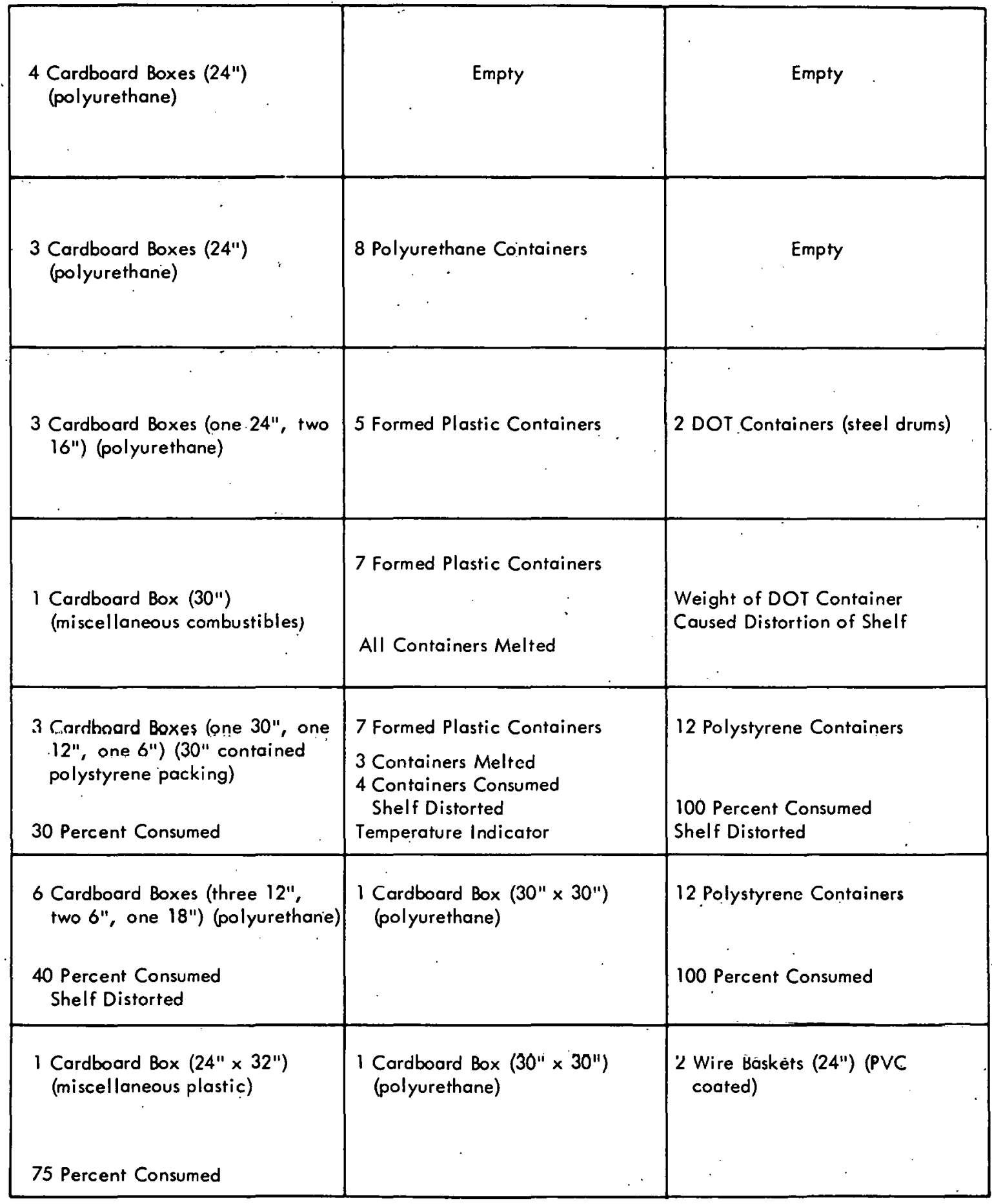

Figure C-4. RACK 2 - WEST SIDE. (Fire Load - $5.2 \times 10^{6} \mathrm{Btu}$ ) 


\begin{tabular}{|c|c|c|}
\hline $\begin{array}{l}120 \text {-Pound Bag of Polystyrene. } \\
\text { Worms } \\
100 \text { Percent Consumed } \\
\text { Shelf Distorted }\end{array}$ & 3 Formed Plastic Containers & 6 Polyethylene Containers \\
\hline $\begin{array}{l}12 \text { Polystyrene Containers } \\
100 \text { Percent Consumed } \\
\text { Shelf Distorted }\end{array}$ & 4 Polyethylene Containers & 3 Polyethylene Containers \\
\hline $\begin{array}{l}12 \text { Polystyrene Containers } \\
100 \text { Percent Consumed } \\
\text { Shelf Distorted }\end{array}$ & $\begin{array}{l}3 \text { Polyethylene Containers } \\
1 \text { Container Melted }\end{array}$ & $\begin{array}{l}3 \text { Polyethylene Containers } \\
\text { All Containers Melted and } \\
\text { Consumed }\end{array}$ \\
\hline $\begin{array}{l}12 \text { Polystyrene Containers } \\
100 \text { Percent Consumed } \\
\text { Shelf Distorted }\end{array}$ & 3 Aluminum Boxes $\left(8^{\prime \prime} \times 8^{\prime \prime}\right)$ & $\begin{array}{l}3 \text { Polyethylene Containers } \\
\text { All Containers Melted and } \\
\text { Consumed }\end{array}$ \\
\hline $\begin{array}{l}4 \text { Polystyrene Containers } \\
1 \text { 20-Pound Bag of Polystyrene } \\
\text { Packing } \\
100 \text { Percent Consumed } \\
\text { Shelf Distorted } \\
\text { Temperature Indicator }\end{array}$ & $\begin{array}{l}8 \text { Aluminum Boxes }\left(8^{\prime \prime} \times 8^{\prime \prime}\right) \\
\text { Temperature Indicator }\end{array}$ & $\begin{array}{l}\text { Cardboard Box }\left(42^{\prime \prime} \times 42^{\prime \prime} \times 22^{\prime \prime}\right) \\
\text { (polystyrene pocking) }\end{array}$ \\
\hline $\begin{array}{l}12 \text { Polystyrene Containers } \\
100 \text { Percent Consumed } \\
\text { Shelf Distorted } \\
\text { Temperature Indicator }\end{array}$ & $\begin{array}{l}\text { 1 Cardboard Box }\left(42^{\prime \prime} \times 42^{\prime \prime} \times 22^{\prime \prime}\right) \\
\text { (polystyrene packing) }\end{array}$ & $\begin{array}{l}100 \text { Percent Consumed } \\
\text { Shelf Distorted }\end{array}$ \\
\hline $\begin{array}{l}12 \text { Polystyrene Containers } \\
100 \text { Percent Consumed } \\
\text { Shelf Distorted }\end{array}$ & 100 Percent Corisumed & $\begin{array}{l}1 \text { Cardboard Box (16" } \times 36 ") \\
\text { (miscellaneous combustibles) } \\
100 \text { Percent Consumed }\end{array}$ \\
\hline
\end{tabular}

Figure C.5. RACK 2 - EAST SIDE. (Fire Load - $3.9 \times 10^{6} \mathrm{Btu}$ ) 


\begin{tabular}{|c|c|c|}
\hline $\begin{array}{l}3 \text { Cardboard Boxes }\left(18^{\prime \prime} \times 20^{\prime \prime}\right) \\
\text { (empty) }\end{array}$ & Empty & Empty \\
\hline $\begin{array}{l}3 \text { Cardboard Boxes }\left(18^{\prime \prime} \times 20^{\prime \prime}\right) \\
\text { (empty) }\end{array}$ & Empty & Empty \\
\hline $\begin{array}{l}3 \text { Cordboard Boxes }\left(18^{\prime \prime} \times 20^{\prime \prime}\right) \\
\text { (empty) } \\
50 \text { Percent Consumed }\end{array}$ & $\begin{array}{l}2 \text { Fiberglas (polyester reinforced) } \\
\text { Containers }\end{array}$ & . \\
\hline $\begin{array}{l}3 \text { Cardboard Boxes }\left(18^{\prime \prime} \times 20^{\prime \prime}\right) \\
\text { (empty) } \\
50 \text { Percent Consumed }\end{array}$ & 2 Fiber Drums (12") & 2 Formed Plastic Containers \\
\hline $\begin{array}{l}3 \text { Cardboard Boxes }\left(18 " \times 20^{\prime \prime}\right) \\
\text { (empty). } \\
90 \text { Percent Consumed }\end{array}$ & 3 Fiber Drums (one 18", two .12") & $\begin{array}{l}2 \text { Birdcages (metal) } \\
\text { Temperature Indicator }\end{array}$ \\
\hline $\begin{array}{l}3 \text { Cardboard Boxes }\left(18^{\prime \prime} \times 20^{\prime \prime}\right) \\
\text { (empty) } \\
100 \text { Percent Consumed }\end{array}$ & $\begin{array}{l}2 \text { Fiber Drums (24") (no lid) } \\
\text { Hole Burned Through Side }\end{array}$ & $\begin{array}{l}9 \text { Polystyrene Containers } \\
100 \text { Percent Consumed } \\
\text { Temperature Indicator }\end{array}$ \\
\hline $\begin{array}{l}3 \text { Cardboard Boxes }\left(18^{\prime \prime} \times 20^{\prime \prime}\right) \\
\text { (empty) }\end{array}$ & $\begin{array}{l}\text { Cardboard Box }\left(24^{\prime \prime} \times 12^{\prime \prime}\right) \\
\text { (polyurethane) }\end{array}$ & $\begin{array}{l}10 \text { Polystyrene Containers } \\
100 \text { Percent Consumed. }\end{array}$ \\
\hline
\end{tabular}

Figure C-6. RACK 3 - WEST SIDE. (Fire Load - $1.7 \times 10^{6}$ Btu) 


\begin{tabular}{|c|c|c|}
\hline 2 Cardboard Boxes (24" x 18"!) & $\begin{array}{l}2 \text { Cardboard Boxes }\left(24^{\prime \prime} \times 18^{\prime \prime}\right) \\
\text { (empty) }\end{array}$ & 3 Polyethylene Containers \\
\hline I Birdcage (metal) & $\begin{array}{l}2 \text { Cardboard Boxes }(24 " \times 18 ") \\
\text { (empty) }\end{array}$ & 3 Formed Plastic Containers \\
\hline I Birdcage (metal) & $\begin{array}{l}1 \text { Fiberglas (polyester reinforced) } \\
\text { Container }\end{array}$ & 3 Formed Plastic Containers \\
\hline Empty & $\begin{array}{l}\text { 1. Fiberglas (polyester reinforced) } \\
\text { Container }\end{array}$ & $\begin{array}{l}3 \text { Cardboard Boxes }\left(18^{\prime \prime} \times 20^{\prime \prime}\right) \\
\text { (empty) }\end{array}$ \\
\hline 2 Birdcages (metal) & $\begin{array}{l}1 \text { Cardboard Box }\left(24^{\prime \prime} \times 18 "\right) \\
\text { (empty) }\end{array}$ & $\begin{array}{l}3 \text { Cardboard Boxes }\left(18^{\prime \prime} \times 20^{\prime \prime}\right) \\
\text { (empty) } \\
\text { I Box Charred }\end{array}$ \\
\hline 10 Polystyrene Containers & $\begin{array}{l}1 \text { Cardboard Box }\left(24^{\prime \prime} \times 18^{\prime \prime}\right) \\
(\text { empty })\end{array}$ & $\begin{array}{l}3 \text { Cardboard Boxes }\left(18^{\prime \prime} \times 20^{\prime \prime}\right) \\
\text { (empty) }\end{array}$ \\
\hline $\begin{array}{l}\text { I Fiberglas (mlyester reinforced) } \\
\text { Container }\end{array}$ & $\begin{array}{l}1 \text { Cardboard Box }\left(24^{\prime \prime} \times 18^{\prime \prime}\right) \\
\text { (empty) } \\
1 \text { Fiberglas (polyester reinforced) } \\
\text { Container }\end{array}$ & $\begin{array}{l}3 \text { Cardboard Boxes }\left(18^{\prime \prime} \times 20^{\prime \prime}\right) \\
\text { (empty) }\end{array}$ \\
\hline
\end{tabular}

Figure C.7. RACK 3 - EAST SIDE. (Fire Load - $1.637 \times 10^{6} \mathrm{Btu}$ ) 


\section{APPENDIX D}

\section{LOADING ARRANGEMENT FOR TEST 4}

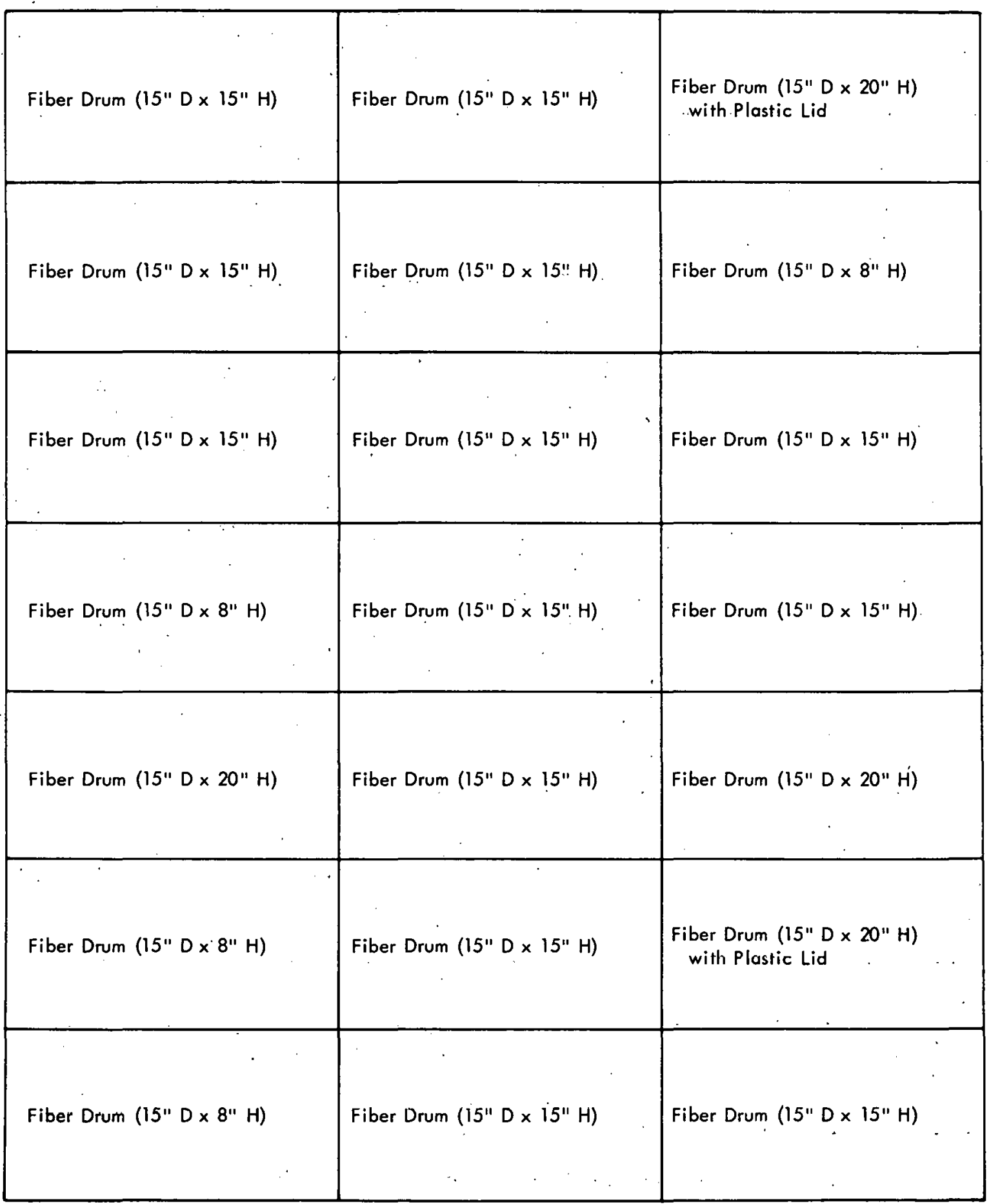

Figure D-1. RACK 1 - WEST SIDE. 


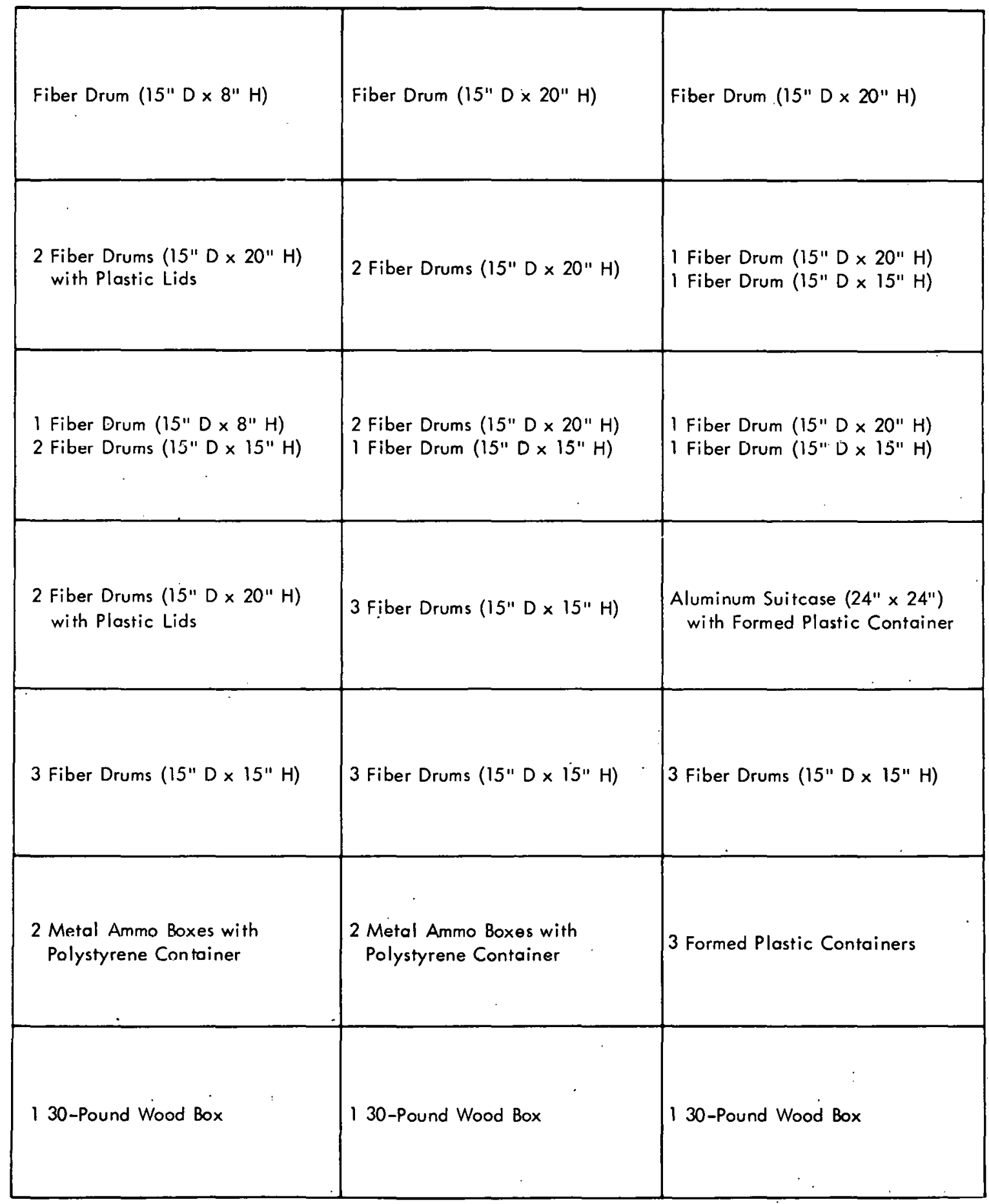

Figure D-2. RACK 1 - EAST SIDE. 


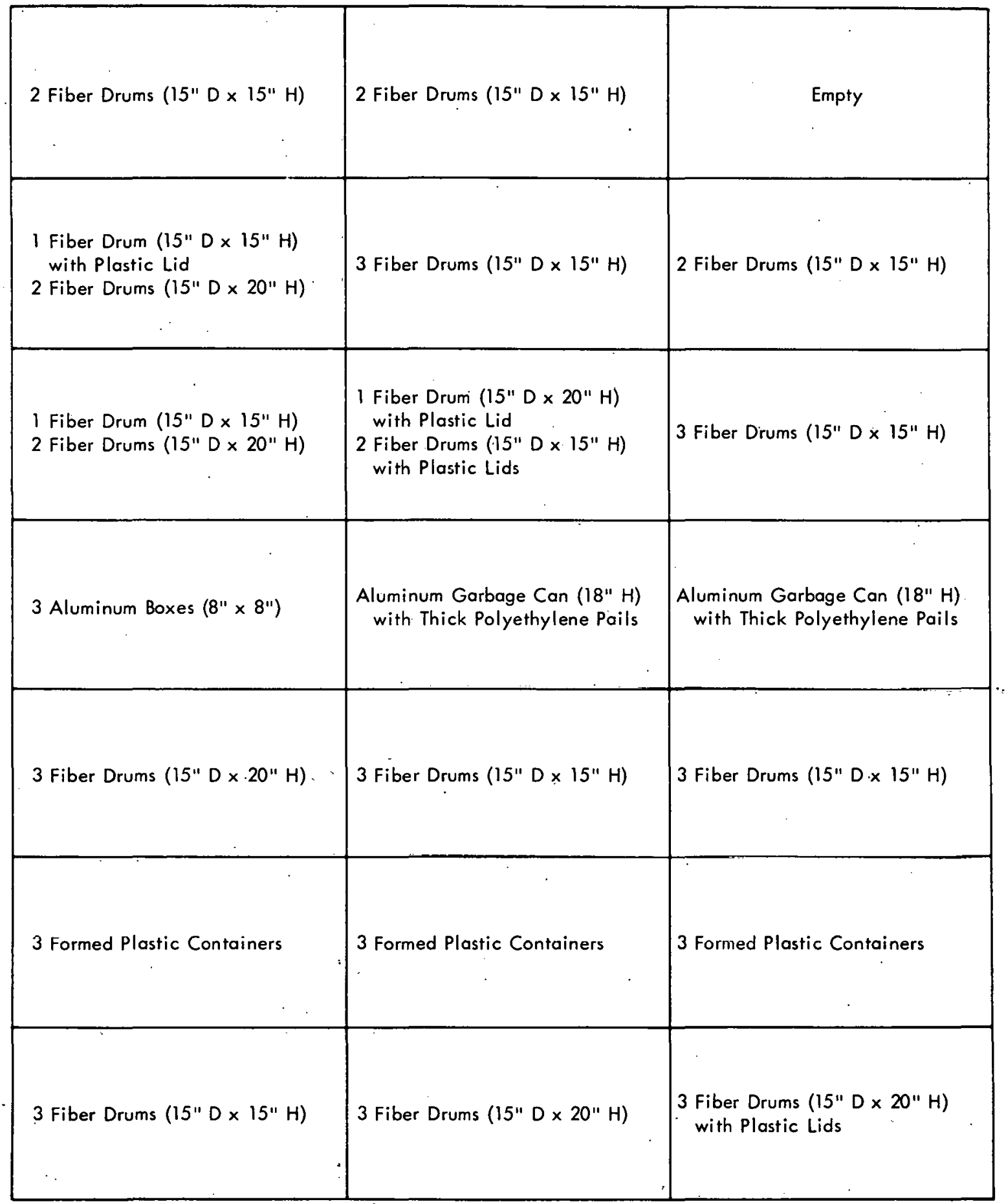

Figure D-3. RACK'2 - WEST SIDE. 


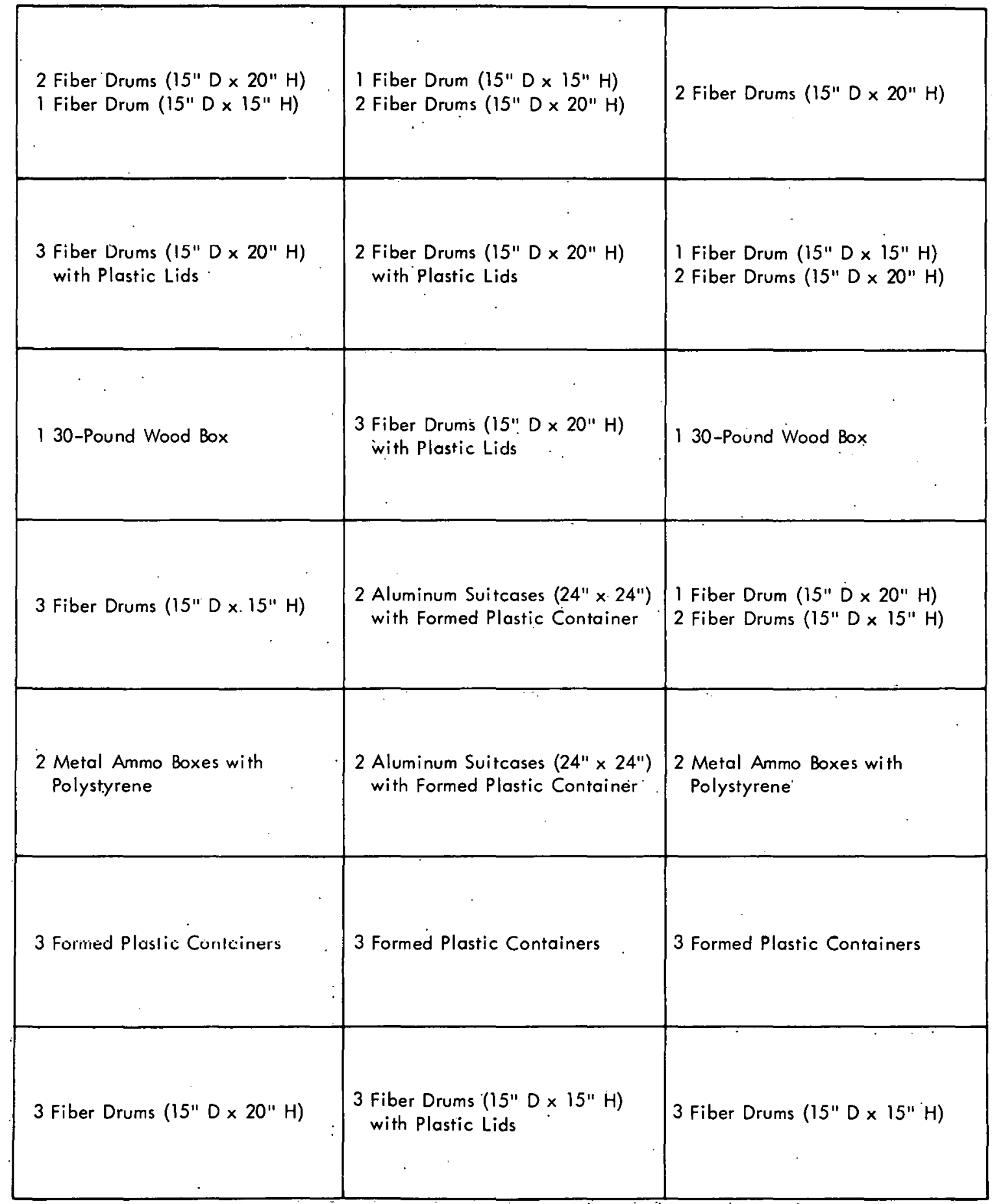

Figure D-4. RACK 2. - EAST SIDE. 


\begin{tabular}{|c|c|c|}
\hline $\begin{array}{l}1 \text { Fiber Drum }\left(15^{\prime \prime} \mathrm{D} \times 20^{\prime \prime} \mathrm{H}\right) \\
1 \text { Fiber Drum }\left(15^{\prime \prime} \mathrm{D} \times 15^{\prime \prime} \mathrm{H}\right)\end{array}$ & Fiber Drum (15" $\left.\mathrm{D} \times 15^{\prime \prime} H\right)$ & Fiber Drum (15" D x 8" H) \\
\hline Fiber Drum $\left(15^{\prime \prime} \mathrm{D} \times 20^{\prime \prime} \mathrm{H}\right)$ & 2 Fiber Drums $\left(15^{\prime \prime} \mathrm{D} \times 15^{\prime \prime} \mathrm{H}\right)$ & Fiber Drum $\left(15^{\prime \prime} \mathrm{D} \times 15^{\prime \prime} \mathrm{H}\right)$ \\
\hline $\begin{array}{l}2 \text { Fiber Drums }\left(15^{\prime \prime} \mathrm{D} \times 20^{\prime \prime} \mathrm{H}\right) \\
\text { with Plastic Lids }\end{array}$ & $\begin{array}{l}2 \text { Fiber Drums }\left(15^{\prime \prime} \mathrm{D} \times 20^{\prime \prime} \mathrm{H}\right) \\
\text { with Plastic Lids }\end{array}$ & Fiber Drum (15" D $\left.\times 8^{\prime \prime} H\right)$ \\
\hline $\begin{array}{l}\text { Aluminum Suitcase }\left(24^{\prime \prime} \times 24^{\prime \prime}\right) \\
\text { with Formed Plastic Containers }\end{array}$ & $\begin{array}{l}2 \text { Fiber Drums }\left(15^{\prime \prime} \mathrm{D} \times 20^{\prime \prime} \mathrm{H}\right) \\
\text { with Plastic Lids }\end{array}$ & Fiber Drum $\left(15^{\prime \prime} \mathrm{D} \times 8 " \mathrm{H}\right)$ \\
\hline 3 Fiber Drums $\left(15^{\prime \prime} \mathrm{D} \times 15^{\prime \prime} \mathrm{H}\right)$ & 3 Fiber Drums $\left(15^{\prime \prime} \mathrm{D} \times 15^{\prime \prime} \mathrm{H}\right)$ & 3 Fiber Drums (15" $\left.\mathrm{D} \times 15^{\prime \prime} \mathrm{H}\right)$ \\
\hline $\begin{array}{l}2 \text { Metal Ammo Boxes with } \\
\text { Polystyrene }\end{array}$ & $\begin{array}{l}2 \text { Metal Ammo Boxes with } \\
\text { Polystyrene }\end{array}$ & 3 Formed Plastic Containers \\
\hline I 30-Pound Wood Box & 130 -Pound Wood Box & 130 -Pound Wood Box \\
\hline
\end{tabular}

Figure D.5. ' RACK 3 - WEST SIDE. 


\begin{tabular}{|c|c|c|}
\hline Fiber Drum $\left(15^{\prime \prime} \mathrm{D} \times 8^{\prime \prime} \mathrm{H}\right)$ & Fiber Drum $\left(15^{\prime \prime} \mathrm{D} \times 15^{\prime \prime} \mathrm{H}\right)$ & Fiber Drum $\left(15^{\prime \prime} \mathrm{D} \times 20 " \mathrm{H}\right)$ \\
\hline $\begin{array}{l}\text { Fiber Drum }\left(15^{\prime \prime} \mathrm{D} \times 20^{\prime \prime} \mathrm{H}\right) \\
\text { with Plastic Lids }\end{array}$ & $\begin{array}{l}\left.\text { Fiber Drum (15" D } \times 2{ }^{\prime \prime} \mathrm{H}\right) \\
\text { with Plastic Lids }\end{array}$ & Fiber Drum $\left(15^{\prime \prime} \mathrm{D} \times 15^{\prime \prime} \mathrm{H}\right)$ \\
\hline $\begin{array}{l}\text { Fiber Drum }\left(15^{\prime \prime} \mathrm{D} \times 20^{\prime \prime} \mathrm{H}\right) \\
\text { with Plastic Lids }\end{array}$ & Fiber Drum (15" D × 8" H) & Fiber Drum (15" D × 20" H) \\
\hline Fiber Drum $\left(15^{\prime \prime} \mathrm{D} \times 15^{\prime \prime} \mathrm{H}\right)$ & Fiber Drum $\left(15^{\prime \prime} \mathrm{D} \times 8^{\prime \prime} \mathrm{H}\right)$ & Fiber Drum $\left(15^{\prime \prime} \mathrm{D} \times 15^{\prime \prime} \mathrm{H}\right)$ \\
\hline Fiber Drum $\left(15^{\prime \prime} \mathrm{D} \times 15^{\prime \prime} \mathrm{H}\right)$ & $\begin{array}{l}\left.\text { Fiber Drum (15" D } \times 15^{\prime \prime} \mathrm{H}\right) \\
\text { with Plastic Lid }\end{array}$ & Fiber Drum $\left(15^{\prime \prime} \mathrm{D} \times 15^{\prime \prime} \mathrm{H}\right)$ \\
\hline Fiber Drum $\left(15^{\prime \prime} \mathrm{D} \times 15^{\prime \prime} \mathrm{H}\right)$ & $\begin{array}{l}\text { Fiber Drum (15" D } \times 20^{\prime \prime} \text { II) } \\
\text { with Plastic Lid }\end{array}$ & Fiber Drum $\left(15^{\prime \prime} \mathrm{D} \times 15^{\prime \prime} \mathrm{H}\right)$ \\
\hline Fiber Drum $\left(15^{\prime \prime} \mathrm{D} \times 15^{\prime \prime} \mathrm{H}\right)$ & $\begin{array}{l}\left.1 \text { Fiber Drum (15" D } \times 20^{\prime \prime} \mathrm{H}\right) \\
\text { with Plastic Lid } \\
1 \text { Fiber Drum }\left(15^{\prime \prime} \mathrm{D} \times 15^{\prime \prime} \mathrm{H}\right) \\
\text { with Plastic Lid }\end{array}$ & 2 Fiber Drums $\left(15^{\prime \prime} \mathrm{D} \times 15^{\prime \prime} \mathrm{H}\right)$ \\
\hline
\end{tabular}

Figure D-6. RACK 3 - EAST SIDE. 


\section{APPENDIX E}

\section{CONTAINER SPECIFICATIONS}

\section{Scope}

These specifications are to apply to all containers entering, leaving, or in use in the $Y-12$ Plant.

\section{Construction}

All outer containers shall be constructed of metal, plywood, or high-density fiber material. Plywood and fiber material shall be painted with a fire-retardant paint. Each painted container shall be stamped to indicate that it has been painted with a fire-retardant coating. There shall be no exposed plastic. Containers may be any suitable shape. Fiber drums and boxes shall have metal bases and lids. Container gaskets shall be noncombustible (neoprene gaskets are unacceptable).

If an inner container is necessary, it may be constructed of material other than that listed for the outer container (eg,foamed polystyrene or polyurethane plastic).

\section{Packing Material}

Packing material (loose material used to cushion or separate individual containers) shall be adequate to protect the item shipped; however, excess material shall be eliminated. Minimum combustibility and heat load shall be a prime consideration in the selection of a packing material. For example, a high content of foamed polystyrene is not acceptable, but a high content of foamed polyurethane plastic with a fire-retardant additive is acceptable.

\section{Size}

Individual containers shall be no larger than $4^{\prime}$ by $18^{\prime \prime}$ by $28^{\prime \prime}$ high, unless otherwise specified.

\section{Sturdiness}

Containers shall meet Interstate Commerce Commission regulations pertaining to shipments.

\section{Handling}

Provisions for fork-lift handling shall be made on all containers heavier than 65 pounds and on large, bulky containers which cannot be handled by one man.

On containers under 65 pounds, which can be handled by one man but too large for easy handling, handles or similar attachments shall be provided.

\section{Venting}

Unless otherwise specified, vents or rupture discs shall be provided for air-tight closed containers to prevent a build up of excess pressures. 